\title{
Taxonomic and geographic variation of the Pinus mugo complex on chloroplast microsatellite markers
}

Runing title: Phylogeography of mountain and peat-bog pines

\begin{abstract}
The high mountain plants of Central and Southern Europe survived the glacial periods in the same mountain ridges, but at lower altitudes and possibly covering larger areas than during interglacials. This implies the high level of species differentiation between isolated mountain ridges. Pinus mugo complex, which includes P. mugo s.s. (Alps, Sudetes, Carpathians, Dynaric Alps and Rhodopes), P. uncinata (Pyrenees and Alps) and $P$. uliginosa (Sudetes and neighbouring mountain ridges) is a good group to examine such a scenario. We screened 44 populations across the geographic range of the complex, using ten cpSSR markers to study (1) taxonomic relations among P. mugo s.s., $P$. uncinata and $P$. uliginosa and (2) genetic and phylogeographic structure in $P$. mugo s.s. and P. uncinata. Allelic combinations of 87 size variants produced a total of 757 haplotypes. Haplotypic diversity was high and similar in every species ( 0.997 , 0.986 and 0.991 , respectively). The highest divergence between haplotypes was observed in P. uliginosa $\left(D_{s h}^{2}=10.29\right)$. The AMOVA revealed that most of the overall genetic variation is explained by the within-population component $\left(F_{S T}=0.121\right.$, $\left.R_{S T}=0.206\right)$ and by the geography $\left(F_{C T}=0.056, R_{C T}=0.083\right)$. The differentiation between P. mugo s.s., $P$. uncinata and $P$. uliginosa is explained by about $5 \%(P<0.001)$ of the total variation. Vicariant gene pools for the complex were identified in the Pyrenees, the Alps with the Tatra Mts., the Sudetes, and the East and South Carpathians along with
\end{abstract}


the Balkan mountains. The phylogeographic structure was observed in P. mugo s.l., P. mugo s.s. and $P$. uncinata. Results support the separate taxonomic status of $P$. uncinata and P. mugo s.s. and possible hybrid origin of P. uliginosa.

Keywords: biogeography, Coniferae, genetic structure, mountain plants, phylogeography, Pinaceae, systematics. 
Introduction

The Quaternary, mainly Pleistocene, climate oscillations with cold periods had influenced the gene pools of organisms in temperate and boreal zones of Europe (Hewitt, 2004; Hewitt \& Godfrey, 1996). In response to Quaternary expansions of the glacial ice sheets, the temperate tree species were generally confined throughout glacial periods to low-latitude refugia. Comparative analyses have revealed the existence of three major refugia located in the Mediterranean peninsulas of Iberia, Italy and the Balkans. During interglacials, the species migrated from these areas (Hewitt, 2004; Petit, 2003). As a consequence of successive founder events during the recolonization process, genetic diversity should be a gradually declining function of distance from refugia (Petit, 2003). This pattern of genetic diversity known as 'southern richness versus northern purity' has been observed in many tree species, which colonized European lowlands (Hewitt \& Godfrey, 1996; Magri et al., 2006). The influence of Pleistocene migrations is well recognized for coniferous forest trees, such as Pinus sylvestris L., Abies alba Mill., Picea abies (L.) H.Karst. (Cheddadi et al., 2013; Dering, Misiorny, Lewandowski, \& Korczyk, 2011; Gömöry, Paule, Krajmerová, Romšáková, \& Longauer, 2012; Liepelt et al., 2009; Pyhäjärvi, Salmela, \& Savolainen, 2007). These migrations are responsible for a partly common geographical pattern of allozyme loci differentiation in Central Europe (Gömöry, Longauer, Paule, Krajmerová, \& Schmidtová, 2010). However, numerous temperate trees also maintained a substantial amount of diversity from the north to the southern European glacial refugia. Such contrasting patterns of diversity are inferred as footprints of cryptic refugia at high latitudes (e.g. in the area around the Carpathians) or may be an effect of a 'suture' zone 
where the divergent colonizing lineages from different refugia met and merged (Petit, 2003; Provan, \& Bennett, 2008; Temunović et al., 2012).

The high mountain plants (alpine, and subalpine sensu Ellenberg \& Leuschner, 2010; Zarzycki et al., 2002) followed another pattern of Pleistocene migration. Their relatively low thermal demands permitted them to survive the glacial periods of Pleistocene in the same mountain ridges, but at lower altitudes and possibly covering larger areas, than during interglacial periods (de Beaulieu et al., 2001; Fauvart et al., 2012; Jankovská, 2008; Obidowicz, 1996; Ronikier, 2011). The genetic differentiation of the subalpine conifer species of central European mountains is recognized for Pinus cembra L. (Höhn et al., 2009; Lendvay, Höhn, Brodbeck, Mîndrescu, \& Gugerli, 2014; Dzialuk et al., 2014; Wojnicka-Półtorak, Celiński, Chudzińska, Prus-Głowacki, \& Niemtur, 2015) and Larix decidua Mill. (Pluess, 2011). Meanwhile, the genetic structure, phylogeography and glacial history of the P. mugo Turra complex are merely partly resolved.

The Pinus mugo complex (P. mugo s.l.) includes P. mugo s.s., P. uncinata Ramond, $P$. uliginosa G.E.Naumann ex Wimmer and $P$. rotundata Link/P. pseudopumilio (Willk.) Beck (Businsky \& Kirschner, 2006). The dwarf mountain pine P. mugo s.s. (P. mugo subsp. mugo sensu Christensen, 1987) is a large, dwarf shrub which occurs in the subalpine zone of the Alps, Sudetes, Carpathians and mountains of the Balkan Peninsula (Jalas \& Suominen, 1973; Ozenda, 1988; Tsaryk, Didukh, Tasenkevich, Waldon, \& Boratyński, 2006). The mountain pine - P. uncinata (P. mugo subsp. uncinata sensu Christensen, 1987) is a monocormic tree known from the Pyrenees, western Alps, Massif Central, Sierra de Cebollera and Sierra de Gúdar (Ozenda, 1988; Villar, Sesé, Franco, \& Ferrández, 1997). The peat-bog pines $-P$. 
uliginosa and $P$. rotundata have intermediate character between $P$. mugo and $P$. uncinata (Fig. 1). They are trees with one-two(-three) stems and occur mainly on the peat-bogs in and around the Sudetes and in the northern Alps (for more details see: (Boratyńska, Boratyński, Lewandowski, 2003; Businsky \& Kirschner, 2006; Christensen, 1987; Heuertz et al., 2010; Lewandowski, Boratyński, \& Mejnartowicz, 2000). The names $P$. uliginosa and $P$. rotundata are sometimes treated as synonyms (Hamerník \& Musil, 2007; Heuertz et al., 2010). The systematic status of the taxa of the P. mugo complex is still disputed (Boratyńska et al., 2003; Businsky \& Kirschner, 2006; Hamerník \& Musil, 2007; Heuertz et al., 2010). However, we treat them as the P. mugo complex in this study, but using the names $P$. uncinata, $P$. mugo s.s. and $P$. uliginosa to indicate a particular taxon.

To date, only Pyrenean, western- and central Alpine, West Carpathian, Sudetan and a few peripheral populations of the $P$. mugo complex have been used in comparative studies of genetic diversity (Celiński, Zbránková, Wojnicka-Półtorak, \& Chudzińska, 2015; Dzialuk et al., 2009; Dzialuk, Boratyński, Boratyńska, \& Burczyk, 2012; Heuertz et al., 2010; Wachowiak, Boratyńska, \& Cavers, 2013; Wachowiak, Palmé, \& Savolainen, 2011). Moreover, in the East- and South-Carpathians, as well as in the Balkans, the genetic diversity and differentiation were assessed separately (Sannikov, Petrova, Schweingruber, Egorov, \& Parpan, 2011; Slavov \& Zhelev, 2004). The high level of genetic differentiation between distinct mountain ranges and lower level of differences among populations within the same mountain range was observed in the $P$. mugo complex using DNA markers. The differentiation of $P$. uncinata in the south-western (Dzialuk et al., 2009) and of P. uncinata, P. mugo s.s. and P. rotundata/P. ×pseudopumilio in the western part of the geographic range of the 
complex confirmed the geographic pattern of genetic variation (Heuertz et al., 2010). Also, differences among Sudetan, Carpathian and Alpine populations of $P$. mugo s.s followed this trend (Boratyńska et al., 2014; Dzialuk et al., 2012). No clear taxonomic and/or geographic structure of the complex was found using twelve nuclear loci, but there was a geographic structure for $n a d 1$ and nad2 mitochondrial DNA regions (Wachowiak et al., 2013).

As shown by Heuertz et al. (2010), based on data from three chloroplast microsatellites (cpSSR), in western Europe two main distinct vicariant gene pools are present, the Pyrenean and Alpine, with several smaller clusters of peripheral populations of the P. mugo complex. This suggests that Pyrenean and Alpine populations were recolonized respectively by $P$. uncinata and $P$. uncinata/P. mugo s.s. from independent multiple glacial refugia located within these mountain chains. Although Heuertz et al. (2010) did not include populations from the Balkans, they predicted a third refugium for P. mugo s.s. within the Balkan Peninsula. Unfortunately, the genetic data could not be compared with isopollen maps because pollen grains of $P$. mugo complex species are very similar to other Diploxylon pines and have not been distinguished during palynological investigations (e.g. de Beaulieu et al., 2001; Fauvart et al., 2012; Jankovská, 2008; Obidowicz, 1996). Only scarce pre-Holocene macrofossils data are available, mostly from the low areas of the mountain ridges (de Beaulieu et al., 2001; Fauvart et al., 2012; Obidowicz, 1996).

In this study, we aimed to understand genetic variation and structure among populations of $P$. mugo complex across most of the taxa range. More specifically, our objectives were (1) to identify the genetically homogenous groups of populations (2) to investigate the molecular distinctiveness and the taxonomic relationships between $P$. 
mugo s.s., P. uncinata and P. uliginosa (3) to assess whether observed patterns of differentiation are better explained by geographical distance or taxonomy and (4) to describe the potential glacial history of the mountain pines in Europe. We hypothesised that genetic differentiation will confirm the distinctiveness between $P$. mugo s.s and $P$. uncinata, and an intermediate between these two taxa character of $P$. uliginosa (Christensen, 1987). We also expect the genetic differentiation and diversity of the whole geographic range of $P$. mugo s.l. to be influenced by the natural physical barriers. In Europe, the Mediterranean Sea in the south and the east-west orientation of the main mountain ranges of the Alps and the Pyrenees acted as a barrier preventing the lowland and sub-mountain species from spreading during cold and warm periods (Taberlet, Fumagalli, Wust-Saucy, \& Cosson, 1998). At the same time, the mountain ridges function as refugia for the high-mountain and arctic high-mountain plants.

Material and methods

Population sampling and cpSSR genotyping

The taxa of the P. mugo complex are common at and above the treeline in mountain areas. Sampling was conducted in accordance with national and international guidelines, and the collection of 5 needles does not represent a threat for the sampled individuals. We obtained authorization from the Polish Ministry of the Environment for the populations M TM 1, M TM 2, M GM 4, M GM 5, M GM 6, UL BAT, UL TOP, UL WEG, and no permission was needed for the other sites. Forty-four natural populations were sampled within the entire geographic range of the species, except for isolated localities in the north-western Alps, Jura and Vosges. Needles were collected from 1331 adult, cone bearing individuals of $P$. mugo s.s., $P$. uncinata and $P$. uliginosa, distributed 
in 31, 10 and 3 natural populations, respectively (Table 1). The taxa were identified in the field using ecological and morphological characteristics: P. mugo s.s. as a highaltitude, prostrate shrub with \pm relatively small, \pm symmetric cones and thin cone scales; P. uncinata as a high-altitude, monocormic tree, bearing large, asymmetric cones with hooked, shovel-like umbos on the scales; P. uliginosa as a montane peat-bog tree of 12(-3) stems and small, asymmetric cones with prominent but not shovel-like umbos and relatively thick scales (Fig. 1). To avoid the collection of clones, individuals of P. mugo s.s sampled within each population were spaced at least $40 \mathrm{~m}$ apart (Boratyńska, Marcysiak, \& Boratyński, 2005). Data from 18 populations used in previous studies (Dzialuk et al., 2009; Dzialuk et al., 2012) were reanalysed.

Total DNA was extracted following the protocol of (Doyle \& Doyle, 1990). Chloroplast DNA variation was analysed in single multiplex PCR reaction of ten pairs of microsatellite primers originally characterized in P. sylvestris: Pt26081, Pt36480, Pt45002, Pt71936, Pt15169, Pt30204 (Vendramin, Lelli, Rossi, \& Morgante, 1996) and PCP1289, PCP41131, PCP87314, PCP102652 (Provan et al., 1998). The DNA amplification was carried out in $10 \mu \mathrm{l}$ volumes using a PTC-200 thermocycler (MJ Research). The PCR started with the denaturation phase at $94^{\circ} \mathrm{C}$ for $5 \mathrm{~min}$. We then performed 30 cycles with denaturation at $94^{\circ} \mathrm{C}$ for $30 \mathrm{~s}$, annealing at $50^{\circ} \mathrm{C}$ for $1 \mathrm{~min}$ and extension at $72^{\circ} \mathrm{C}$ for $1 \mathrm{~min}(10 \mathrm{~min}$ for the last one). The reactions consisted of $30 \mathrm{ng}$ of template DNA, 1x Qiagen PCR buffer, $4.0 \mathrm{mM} \mathrm{MgCl}_{2}, 0.2 \mathrm{mM}$ each of dNTP, 25$250 \mathrm{nM}$ each of forward and revers primers (Table 2), $5 \mu \mathrm{g} / \mu \mathrm{l}$ of BSA and $0.25 \mathrm{U}$ of Taq Polymerase (Qiagen). 
The PCR products were sized by using the capillary sequencer ABI PRISM 310 (Applied Biosystems) and the genotypes were scored using the GENESCAN 3.7 and GENOTYPER 3.7 software (Applied Biosystems).

\section{Genetic diversity}

For each tree, the haplotype was defined as the unique combination of alleles across the ten microsatellite loci. Haplotype variations were calculated at the population and taxa levels by estimating: number of haplotypes $\left(A_{h}\right)$, effective number of haplotypes $\left(N_{e}\right)$, number of private haplotypes $\left(P_{h}\right)$ and unbiased haplotype diversity $\left(H_{e}\right)$ using GenAlEx 6.501 (Peakall \& Smouse, 2006). In order to correct for the unequal sample sizes within populations a rarefaction analysis was performed with HP-Rare 1.0 (Kalinowski, 2005). Within-population genetic distance between haplotypes $\left(D_{s h}^{2}\right)$ (Vendramin, Anzidei, Madaghiele, \& Bucci, 1998), as defined by Goldstein, Linares, Cavalli-Sforza, \& Feldman (1995), was also computed. This distance is based on the differences among the number of repeat units at the microsatellite regions (stepwise mutation model, SMM) considering the chloroplast DNA as a single locus. Moreover, haplotypic richness was estimated by 'proportion distinguishable' (PD), which is the ratio of haplotypes relative to the total number of individuals analyzed in the population (Ellstrand \& Roose, 1987). For descriptive purposes, correlations between characteristics of genetic diversity and altitude as well as longitude/latitude were quantified using the Spearman rank correlation coefficient $\left(r_{S}\right)$. Finally, to compare the genetic diversity parameters between taxa, we used the non-parametric Kruskal-Wallis test. All the analyses were performed with PAST 2.17 software (Hammer, Harper, \& Ryan, 2001). 
Genetic and taxonomic structure

Population genetic structure was examined using analysis of molecular variance (AMOVA) in Arlequin 3.5.1.2 (Excoffier, \& Lischer, 2010). The analyses were based on the number of different alleles $\left(F_{S T}\right.$-like, based on unordered alleles) and on the sum of the squared differences ( $R_{S T}$-like, based on ordered alleles). Hierarchical AMOVA was conducted to partition components of genetic variation among taxa (P. mugo s.s., $P$. uncinata, P. uliginosa) and regions (Sierra Cebolera; Sierra de Gúdar; Pyrenees; Massif Central; Alps; Apennines; Sudetes; Dinaric Alps; Balkan Mts.; West Carpathians; East and South Carpathians). The taxa and geographical regions were treated as groups resulting in three hierarchical levels of differentiation: among taxa/geographical regions (fixation indexes $F_{C T}$ and $R_{C T}$ ), among populations within taxa/geographical regions (fixation indexes $F_{S C}$ and $R_{S C}$ ) and within populations (fixation indexes $F_{S T}$ and $R_{S T}$ ). To better understand the relationships among taxa, comparison of $F_{\mathrm{ST}}$ values and AMOVA between pair of taxa were performed. The significance of the results was tested using 20,000 random permutations of the data. PCoA was also used to investigate the molecular distinctiveness of the three taxa.

To discern whether populations are differentiated due to isolation by distance (Wright, 1965), a Mantel test with 9,999 random permutations was applied to analyze the association between genetic $\left[F_{S T} /\left(1-F_{S T}\right)\right]$ and geographic distances for each sampled population using GenAlEx 6.501 (Peakall, \& Smouse, 2006). The test was conducted for P. mugo s.1., as well as for P. mugo s.s., P. uncinata and P. uliginosa, separately. The geographic distances between populations have been retrieved from geographic coordinates (Table 1), using GenAlEx 6.501 (Peakall, \& Smouse, 2006). 
Phylogeographic patterns

A Bayesian approach was used to further explore the population structures using both a non-spatial and a spatial genetic mixture analysis implemented in BAPS 5.3 software (Corander, Waldmann, \& Sillanpää, 2003). Genetically homogeneous groups of populations were inferred based on a linked loci model because the chloroplast genome does not genetically recombine and may be viewed as a single locus or circular haploid chromosome with non-recombining loci (Vendramin et al., 1998). In order to test the reproducibility of the results, for the maximum number of clusters $(\mathrm{K})$ ranging from $\mathrm{K}=$ 1 up to $\mathrm{K}=44$, we ran the model ten times. The most likely partition of populations into $\mathrm{K}$ clusters was identified as the one with the highest log likelihood.

To identify clusters of populations sharing similar cpSSR compositions, based on the allelic frequencies matrix and the assumption of a stepwise mutation model (SMM), we computed 1,000 pairwise shared allele distance $D_{S A}$ matrices (Chakraborty, \& Jin, 1993) in PowerMarker (Liu, \& Muse, 2005). A consensus tree was made using the programs CONSENSE and DRAWTREE of the package PHYLIP version 3.68 (Felsenstein, 1989). In the preliminary tests, the proportion of variation in the genetic distance matrix that is explained by the tree $\left(\mathrm{R}^{2}\right)$ was calculated using TreeFit software (Kalinowski, 2009). If $\mathrm{R}^{2}$ is near 1.0 , the tree represents a good summary of the genetic relationships shown in the distance matrix. The neighbour joining $(\mathrm{NJ})$ method was used for tree building, because the algorithm was considered to be preferable to the unweighted pair group method with arithmetic mean (UPGMA). To validate and further define naturally occurring genetic clusters, GenAlEx 6.501 software (Peakall, \& 
Smouse, 2006) was used to calculate principal coordinate analysis (PCoA) on the pairwise genetic distance matrix for $D_{\mathrm{A}}(\mathrm{Nei}$, Tajima, \& Tateno, 1983).

The presence of phylogeographical structure was tested by comparing the observed $R_{S T}$ value with its value after permuting allele sizes within loci $\left(p R_{S T}\right)$ using SPAGeDi 1.3 (Hardy \& Vekemans, 2002). This analysis indicates whether shifts in allele size resulting from stepwise mutations contribute to population differentiation (Hardy, Charbonnel, Fréville, \& Heuertz, 2003). We applied the permutation tests (20,000 permutations) on the whole dataset as well as on each taxon ( $P$. mugo s.s., $P$. uncinata and P. uliginosa) and geographical region (Alps, Sudetes, E and S Carpathians, W Carpathians, Balkan Mts.) separately, with the expectation that mutations contributed unevenly to the taxon/region history. If $R_{S T}$ is significantly higher than $p R_{S T}$, then allele size mutations contributed to population differentiation and can be interpreted as phylogeographical structure in which closely related plastid haplotypes are located in nearby populations (Hardy, \& Vekemans, 2002).

\section{Results}

Genetic diversity and structure

The 10 microsatellite loci yielded a total of 87 size variants (alleles), including 6-15 alleles per locus among 1331 individuals of the P. mugo complex. The most common alleles and the allele sizes ranges were roughly the same in all taxa. We observed only small size shifts at the loci Pt36480 and Pt 71936 in P. uliginosa as well as at loci PCP41131 and PCP102652 in P. uncinata. However, the highest differences in fragment lengths were observed at the locus PCP1289, where the maximum length alleles were 106, 110 and 103 base pairs (bp) for P. mugo s.s., $P$. uncinata and $P$. 
uligionosa, respectively (Table 2). Allelic combinations produced a total of 757 haplotypes, from which about $74 \%$ were exclusive to a given population (private haplotypes). The most abundant haplotype occurred only in 25 individuals of $P$. mugo s.1.

About $95 \%$ of the total haplotypes were taxon specific $(P$. mugo s.s. $=74.2 \% ; P$. uncinata $=18.4 \%$ and $P$. uliginosa $=7.3 \%$ ). Only $4.7 \%$ of the haplotypes were shared between taxa (P. mugo s.s. and $P$. uncinata $=2.5 \%, P$. mugo s.s. and $P$. uliginosa $=$ $1.2 \%, P$. uncinata and $P$. uliginosa $=0.7 \%, P$. mugo s.s., $P$. uncinata and $P$. uliginosa $=$ $0.3 \%$ ). As indicated by $A_{h}, \% \mathrm{PD}, P_{h}$ and $N_{e}$ (Table 3 ), the highest values of haplotype diversity were observed in P. mugo s.s.: M A1, M A3, M A6, M DYN1, M DYN2 in the Alps; M CAR4, M CAR6, M CAR7, M LT in the Carpathians; M RM1 and M VIT in the Balkan Mts. as well as in P. uncinata (U MAS2, Massif Central) and P. uliginosa (UL WEG, Sudetes). The lowest values of haplotype diversity were noted in M A10 (Alps), M RM2 (Balkan Mts.), U GUD (Cordillera Iberica) and UL BAT (Sudetes). The within-population diversity parameters showed that the mean haplotypic richness (23.61, 22.50 and 22.64) and the haplotypic diversity $(0.975,0.963$ and 0.973$)$ were high and similar in $P$. mugo s.s., $P$. uncinata and $P$. uliginosa, respectively. We did not find a direct connection between geographic position of population (longi-/ lati-/ altitude) and level of diversity, neither within the P. mugo complex, nor in particular taxa. The highest divergence between haplotypes $D_{s h}^{2}$ was observed in UL TOP, U MAS2 and U CEB. The genetic differentiation between populations (pairwise $F_{S T}$ ) was high and mostly significant. However, the differences in genetic diversity parameters between the taxa of the $P$. mugo complex were not significant $(P>0.05$, Kruskal-Wallis test, Table 3). 
The Mantel permutation test proved a significant correlation between genetic and geographic distance $\left(\mathrm{R}^{2}=0.205, P<0.0001\right)$, suggesting a pattern of isolation by distance (IBD) in the P. mugo complex. When the taxa were analysed separately, the test was statistically significant for $P$. mugo s.s. $\left(\mathrm{R}^{2}=0.084, P<0.0001\right)$ but not for remaining taxa (Fig. 2).

The non-hierarchical AMOVA based on unordered alleles $\left(F_{S T}\right)$ and ordered alleles $\left(R_{S T}\right)$ (Table 4$)$ revealed higher genetic diversity within populations $(87.94 \%$ and $79.41 \%$, respectively) in comparison with differentiation among populations of the $P$. mugo complex ( $12.06 \%$ and $20.59 \%, P<0.001$ in both cases $)$. This pattern of genetic structure in P. mugo s.l. was confirmed by the geographical grouping AMOVA $\left(F_{C T}=0.056, R_{C T}=0.083, P<0.001\right)$.

Taxonomic relations Hierarchical AMOVA indicated that barely $5 \%$ of genetic variance was accounted for by the species grouping $\left(F_{C T}=0.051, R_{C T}=0.050, P<0.001\right)$, while most of the diversity was still located within populations (Table 3). In the PCoA the first two axes explained $66.8 \%$ and $33.20 \%$ of the variance and revealed distinct separation between the taxa (Fig. 4.4). The most differentiated pair of taxa was $P$. mugo s.s. and $P$. uncinata $\left(F_{\mathrm{CT}}=\right.$ 0.064 and $\left.R_{\mathrm{CT}}=0.063\right)$. Much lower differences were attributable to differences among P. uncinata and P. uliginosa $\left(F_{\mathrm{CT}}=0.035\right.$ and $R_{\mathrm{CT}}=0.046$, Table 5). Meanwhile, a nonsignificant proportion of variation was among $P$. mugo s.s. and $P$. uliginosa (Table 5). High $F_{\mathrm{ST}}$ values between each pair of three pine taxa were estimated between $P$. mugo s.s. and $P$. uncinata $\left(F_{\mathrm{ST}}=0.699\right)$ as well as $P$. uncinata and $P$. uliginosa $\left(F_{\mathrm{ST}}=0.558\right)$. 
The lowest value was found between $P$. mugo s.s. and $P$. uliginosa $\left(F_{\mathrm{ST}}=0.029\right)$. All $F_{\mathrm{ST}}$ values were significantly different from zero $(P<0.001$, Table 6$)$.

Phylogeographical structure

Bayesian analysis of population structure gave similar results using either a spatial or a non-spatial model for genetic mixture analysis. BAPS showed an optimal partition of the 44 populations into nine or eight genetically distinct groups, respectively (Fig. 3). All the East and South Carpathian populations shared a unique gene-pool and were assigned to cluster 4, which also included populations from the Balkan Mts., except for M RM2. Populations from the Alps were assigned to two different groups: cluster 2 or cluster 3. Moreover, despite being geographically isolated, both the Tatra and most of the Sudetes populations were assigned to the Alpine cluster 3. The westernmost alpine population of $P$. mugo s.s. (M A11) was grouped with the Apennines (MAPP) in cluster 5 and the easternmost alpine population (M A10) was included into the East Carpathian cluster 4. Similarly, some signs of close association between Alpine cluster 3 and Carpathian cluster 4 were observed in the West Carpathians and the Sudetes. Moreover, the southernmost Dynaric population (M DYN2) was assigned to the Apennines cluster 5 in non-spatial analysis. Most populations of the P. uncinata were included in cluster 6. The remaining population of this taxon was grouped in cluster 7 (U GUD) and cluster 8 (U CEB, A MAS2). Each population of P. uliginosa was assigned to a different cluster (Fig. 3).

The population structure revealed by the NJ dendrogram using shared allele distance $D_{S A}$ and the PCoA graph appeared similar to that inferred from the Bayesian analysis. According to these results, populations of the P. mugo complex clustered into 
four main groups, the Pyrenean, the Alpine and West Carpathian, the Sudetan, and the East and South Carpathian. Only three marginal populations (U GUD, U CEB and U MAS2) were separated from the $P$. uncinata cluster, and all populations of $P$. uliginosa were mixed in one group with marginal populations of P. mugo s.l. (Fig. 4).

A permutation test revealed that $R_{S T}(0.206)$ was significantly higher than the mean permuted $R_{S T}(0.126 ; P=0.0012)$, indicating the geographical association of closely related plastid haplotypes in the P. mugo complex (Table 7). However, this pattern was consistent only for populations of $P$. mugo s.s. $\left(R_{S T}=0.178>p R_{S T}=0.090\right.$; $P<0.001)$ and for P. uncinata $\left(R_{S T}=0.214>p R_{S T}=0.089 ; P<0.001\right)$, but not for $P$. uliginosa $\left(R_{S T}=0.178>p R_{S T}=0.132, P=0.243\right)$. Moreover, analyses within mountain chains indicated that SMM contributed significantly to regional differentiation in $P$. mugo s.s. only in the Alps and East Carpathians. No significant differences were found between observed and permuted $R_{S T}$ in the Sudetes, Tatras and Balkan Mts. (Table 7).

\section{Discussion}

Genetic diversity and differentiation

Due to lack of polymorphic, maternally inherited mitochondrial DNA markers, and only three nuclear microsatellite markers (nSSR) available so far in the P. mugo complex (Celiński, Pawlaczyk, Wojnicka-Półtorak, Chudzińska, \& Prus-Głowacki, 2013), cpSSRs are still markers of the choice in the population genetic study. Their nonrecombinant nature, paternal inheritance and transmission by both pollen and seeds (Neale, \& Sederoff, 1989), make them a useful tool in the study of genetic variation, differentiation and phylogenetic relationships in natural populations of pines (Powell, Morgante, McDevitt, Vendramin, \& Rafalski, 1995). 
Heuertz et al. (2010) identified 100 haplotypes in 786 individuals from 29 populations of the $P$. mugo s.l. in West Europe using 3 cpSSRs. In conclusion, they recommended improving the detection power of the DNA markers to avoid weak cpSSR data differentiation. Thus, we used ten microsatellite loci, which number is high compared with that typically used in these types of studies. Moreover, this approach avoids a downward bias in estimates of genetic differentiation of microsatellites via size homoplasy, which occurs when different copies of a locus are identical in state but not by descent (Estoup, Jarne, \& Cornuet, 2002). The risk of homoplasy is high in the $P$. mugo complex (Provan, Powell, \& Hollingsworth, 2001), because population divergence times are great (Heuertz et al., 2010; Wachowiak et al., 2011) and the stepwise mutations contribute to population differentiation (Dzialuk et al., 2009; Heuertz et al., 2010).

Using 10 chloroplast microsatellites we found 757 haplotypes across 1331 individuals in 44 populations, thus the level of genetic diversity found within the $P$. mugo complex taxa is high and comparable with other pine species studied with cpSSRs in Europe and the Mediterranean (e.g. Afzal-Rafii, \& Dodd, 2007; Bucci et al., 2007; Gómez, Vendramin, González-Martínez, \& Alía, 2005; Kurt, González-Martínez, Alía, \& Isik, 2011; Ribeiro, Plomion, Petit, Vendramin, \& Szmidt, 2001; Robledo-Arnuncio, Collada, Alía, \& Gil, 2005). Interestingly, most populations with a $D_{s h}^{2}$ value higher than 10 (UL TOP, U MAS2, U CEB) were sampled in the isolated localities of the $P$. mugo complex surrounded by extensive $P$. sylvestris stands with hybridization zones (Dzialuk et al., 2009; Jasińska et al., 2010). Introgression from $P$. sylvestris into the $P$. mugo complex was suggested by Heuertz et al. (2010), but a reverse direction of that process has been confirmed by Jasińska et al. (2010). In the Topieliska Nature Reserve 
(UL TOP) the gene pool of $P$. uliginosa might be affected by co-occurring $P$. mugo and P. sylvestris (Wachowiak \& Prus-Głowacki, 2009). Thus, hybridization among mountain pine taxa seems still to be the key future research topic in the P. mugo complex (Wachowiak, Cavers, \& Żukowska, 2015; Wachowiak, Żukowska, Wójkiewicz, Cavers, \& Litkowiec, 2016) and introgression should be further distinguished with suitable DNA markers.

Despite adaptation to local conditions resulting sometimes in a strong differentiation in quantitative traits, pines show generally only low genetic differentiation at neutral markers (Karhu et al., 1996; Savolainen, Pyhäjärvi, \& Knürr, 2007), mainly due to effective pollen-mediated gene flow (Muona \& Harju, 1989). Pinus mugo s.l. shows only weak genetic differentiation in West Europe $\left(F_{S T}=0.076\right.$, $N_{S T}=0.263$, see Heuertz et al., 2010). Meanwhile, the level of genetic differentiation in our study $\left(F_{S T}=0.121\right)$ is one of the highest revealed between populations of $P$. mugo s.l. to date. It may be explained by the fact that this attempt was the nearest thing to a range-wide study, based on a relatively high number of cpSSR markers.

Taxonomic differentiation

As stated by Heuertz et al. (2010), the genetic variation of $P$. mugo agg. in the western part of the geographic range is structured according to geography but not morphology and taxonomy. Our results indicated that geography and taxonomy are relatively similar determinants of genetic structure at cpSSRs (Table 4). These somewhat contradictory results could be explained by differences in sampling. Heuertz et al. (2010) collected materials from 29 populations in the western part of the complex' geographic range, where $P$. uncinata, P. mugo s.s. and P. rotundata/P. × pseudopumilio were represented 
by 17, 4 and 8 populations, respectively. The $P$. rotundata/P. $\times$ pseudopumilio are treated as synonyms of P. uliginosa (Christensen, 1987). In fact, Heuertz et al.’s (2010) sampling area corresponded mostly to the range-wide sampling for P. uncinata and relatively few westernmost populations of other taxa. Additionally, P. rotundata/P. ×pseudopumilio potentially represented hybrids between $P$. uncinata and $P$. mugo (Christensen, 1987), which could blur the difference between the last taxa. Populations of $P$. mugo s.s sampled from the central and eastern parts of their geographic range allow us to find both geographic and taxonomic differentiation within P. mugo s.l. Moreover, the use of $10 \mathrm{cpSSRs}$ may also have played an important role, providing genetic support for morphological taxa of mountain pines in our study. We have well distinguished $P$. uncinata, $P$. mugo s.s. and to some degree also P. uliginosa (Figs 3 and 4), as likewise in the biometric study (Boratyńska, Jasińska \& Boratyński, 2015, Fig. 2). The differences between taxa in $P$. mugo complex have been reported during last decades using allozymes (Lewandowski et al., 2000; Prus-Głowacki, Bajus, \& Ratyńska, 1998), DNA markers (Danusevičius et al., 2013) and chemosystematic markers (Bonikowski, Celiński, Wojnicka-Półtorak, \& Maliński, 2015; Celiński, Bonikowski, Wojnicka-Półtorak, Chudzińska, \& Maliński, 2015).

NJ tree and PCoA (Fig. 4) support the suggestion that P. uncinata evolved in the western, and P. mugo s.s. in the eastern regions, and hybridized giving P. uliginosa/P. rotundata in the northern parts of the Alps, Sudetes and West Carpathians (Christensen, 1987). Particular populations of that taxon have a relict character, are isolated from each other and evolved in separation, which could have influenced morphological differences among them, detected on the allozyme markers (e.g. Lewandowski, Samoćko, Boratyńska, \& Boratyński, 2002; Wachowiak \& Prus-Głowacki, 2009) and in biometric 
studies (e.g. Boratyńska et al., 2003, 2015; Boratyńska \& Lewandowska, 2009; Staszkiewicz, \& Tyszkiewicz 1976). The differences between populations of $P$. uliginosa may be enhanced by different demographic events, founder effects, selection pressure on the local, isolated localities, and also by hybridization with $P$. mugo s.s. or even with P. sylvestris (Boratyński, Boratyńska, Lewandowski, Gołąb, \& Kiciński, 2003; Heuertz et al., 2010; Lewandowski et al., 2002; Wachowiak et al., 2011).

Geographic pattern of diversity and differentiation The long distance between marginal East (M CAR7) and West (UL CEB) populations of $P$. mugo s.1., ca 2.5 times longer than between northern- (UL WEG) and southernmost (M APP) populations implies larger genetic distances between the East-Carpathian and Pyrenean populations, and such differences have been detected. Also, the significant correlation between genetic and geographic distances (Fig. 2) suggests isolation by distance (IBD). And in fact, the results of the Bayesian analyses, the cluster analysis of shared allele distance $D_{S A}$ (Chakraborty \& Jin, 1993) and PCoA of Nei's unbiased genetic distances revealed a subdivision of populations of $P$. mugo s.l. into at least four core geographic groups, the two detected earlier by Heuertz et al. (2010) and two others, the East-Carpathian and Sudetan, with several clusters of the marginal populations (Figs 3 and 4). This grouping is similar to that detected on the morphological characteristics where, however, Sudetan populations fell into AlpineWest Carpathian populations, but forming among them a compact cluster (compare Fig. 3 with Boratyńska et al., 2015, Fig. 5). It is worth noting that the IBD concerned only $P$. mugo s.1. and, on a much lower level, P. mugo s.s., but not the other taxa (Fig. 2). These confirm the distinct character of the Pyrenean group, which contains $P$. uncinata and 
differences between Alpine - West Carpathian and East Carpathian populations of $P$. mugo s.s. The differences between Alpine and East Carpathian populations of $P$. mugo s.l. were also detected using allozymes (Sannikov et al., 2011), morphological cone characteristics (Staszkiewicz, \& Tyszkiewicz, 1976) and cone and needle characteristics (Boratyńska et al., 2005; 2015).

The high level of genetic distinctiveness of the East- and South-Carpathian when compared to all the other populations of $P$. mugo s.s. could be explained by long lasting, spatial isolation among them during Pleistocene (Latałowa, Tobolski, \& Nalepka, 2004; Magyari et al., 2012). Long-lasting isolation is a reason for independent genetic processes, exposition of particular populations to different environmental pressures and distinct demographic events, such as have been recognized in populations of several high-mountain plant taxa (e.g. Ronikier, 2011; Stachurska-Swakoń, Cieślak, \& Ronikier, 2013).

We also detected some intermingling of populations from different regions (Figs 3 and 4). The presence of populations of different origin within the Alpine-West Carpathian group of populations could indicate the possible gene flow between the East Alps, Sudetes, Carpathians, Dinaric Alps and Balkan populations, as proposed in Fig. 5. This could have taken place during glacial periods, when the vertical geographic range of $P$. mugo s.l. was reduced, but covered a broader area, compared to that of the present day (e.g. Benito Garzón, Sánchez de Dios, \& Sáinz Ollero, 2007; Burga, 1988; de Beaulieu et al., 2001; Jankovská, 2008; Magyari et al., 2012; Wohlfarth et al., 2001). The Balkan populations, which have been suggested by Heuertz et al. (2010) as constituting a possible different gene pool, appeared genetically heterogeneous, with influence from the East and South Carpathian and Alpine gene pools (Figs 3 and 4). 
Again, this is similar to that described in reference to morphological characters, by Boratyńska et al. (2015). Inversely, the influence of a Balkan to Alpine gene pool of Abies alba has been detected by Liepelt et al. (2009), but $A$. alba is a montane, not subalpine species.

The migration history of $P$. mugo s.l. could be better understood when information on its possible micro-refugia detected on the palynological data be considered. The pre-Holocene findings of the species were reported from the Bohemian Carpathians and Sudetes (Jankovská, 2008), around the Tatras (Obidowicz, 1996) and from north-western and southern Romania (Magyari et al., 2012; Wohlfarth et al., 2001). The populations of $P$. mugo from these regions also revealed specific mitochondrial haplotypes (Wachowiak et al., 2013).

Our results generally did not support the hypothesis that population differentiation within particular massifs was at a lower level than between different mountain ridges (Table 4). The results of AMOVA indicate a small (about 5.5\%) but statistically significant percentage of variation among the 11 main regions of occurrence, but a slightly higher (about 7.1\%) and also significant percentage of variation among populations within regions. This only partly confirms our hypothesis regarding the long-lasting isolation of populations in particular mountain massifs, but also indicates the high level of differences within the largest of them. Such a pattern of differentiation could be explained by the extensive populations of the species, which produced great amounts of pollen, transported over relatively large distances (Burczyk, \& Chalupka, 1997; Muona, \& Harju, 1989; Smouse, Dyer, Westfall, \& Sork, 2001; Wachowiak et al., 2011). The high level of differences between populations within mountain ridges concerned first of all the Alps and Carpathians, which have several 
separate massifs high enough for a subalpine vegetation belt to be developed. Recently, using SNPs located in genes encoding proteins, Mosca et al. (2012) found a clear separation between eastern and western Alpine populations of $P$. mugo, which was not observed in studies based on neutral markers (Heuertz et al., 2010; Monteleone, Ferrazzini, \& Belletti, 2006; Wachowiak et al., 2013). She also found that genetic variation of P. cembra, Larix decidua and Abies alba is structured according to geographic regions of the Alps, which corresponds with the general phytogeographic pattern of plant differentiation in the Alps (Thiel-Egenter et al., 2011).

Comparisons of $R_{S T}$ and $p R_{S T}$ revealed a strong signal for phylogeographic structure in $P$. mugo s.s. and $P$. uncinata, but not in $P$. uliginosa, indicating a different glacial history of the taxa. Moreover, a signature of stepwise mutational events in differentiation between Alpine and East and South Carpathian populations of P. mugo s.s. suggest a relatively stable demographic history that would be consistent with populations having persisted in situ at least during the last full glacial stage (AfzalRafii, \& Dodd, 2007). Thus, our data provide support for the glacial refugia of P. mugo s.s. in the Alps and the Carpathians. Conversely, in the Sudetes, the West Carpathians and the Balkan Mts. populations of $P$. mugo s.s., as well as in populations of $P$. uliginosa, a stepwise mutation process did not contribute to genetic differentiation, so the mutation rate is negligible compared to migration or drift. Therefore, these populations might suffer from decolonization processes following glacial maxima.

\section{Conclusion}

The phylogeographical structure in the $P$. mugo complex, and separately in $P$. mugo s.s. and $P$. uncinata, has been detected. Four gene pools could be distinguished in the $P$. 
mugo complex, the Pyrenean including P. uncinata, the Alpine - West Carpathian, Sudetan and East and South Carpathian all iuncluding $P$. mugo s.s. The most of the Balkan mountain populations are placed in the East and South Carpathian group of populations. Within these four gene pools, the groups of populations from the isolated mountain massifs revealed further differentiation inside $P$. uncinata (3 clusters) and $P$. mugo s.s. (6 clusters). The populations of $P$. uliginosa fall into $P$. mugo s.s. except of one, which formed separate cluster. The revealed differentiation and genetic distances between $P$. uncinata, $P$. mugo s.s. and the $P$. uliginosa supports their separate taxonomic status, but the relation of the latter taxon is closer to $P$. mugo s.s. than to $P$. uncinata.

\section{Acknowledgements}

We would like to thank prof. Yakiv P. Didukh from NASU Botanical Institute in Kiev, prof. Roman Gout from UNFTU Department of Forestry in Lviv, Dr. Josep M.

Montserrat from the Botanical Institute of Barcelona, Dr. to C. Farkas from the Brasov Forest Faculty, Romania, the authorities of Karkonosze and Tatra National Parks in Poland for their valuable help during field work, help and assistance in plant material collection and Ewa Sztupecka for technical assistance in the laboratory work. This work was supported by the Polish Ministry of Science under Grants No. 2P04C 018 29, 6P04G 06016, 2P06L 04628 and NN303 360535 and by Institute of Dendrology of Polish Academy of Sciences under Statutory Activity. The collection of plant material was made possible thanks to the cooperation between CSIC (Spanish Research Council) and PAS (Polish Academy of Sciences), NASU (National Academy of Sciences of 
Ukraine) and PAS, KWU (Kazimierz Wielki University) and UNFTU (Ukrainian National Forest-Technical University).

Data Archiving Statement cpSSR data has been deposited in TreeGenes database (the TGDR Accession number: TGDR016).

References

Afzal-Rafii, Z., \& Dodd, R. S. (2007). Chloroplast DNA supports a hypothesis of glacial refugia over postglacial recolonization in disjunct populations of black pine (Pinus nigra) in western Europe. Molecular Ecology, 16, 723-736. doi: 10.1111/j.1365-294X.2006.03183.x

Benito Garzón, M., Sánchez de Dios, R., \& Sáinz Ollero, H. (2007). Predictive modelling of tree species distributions on the Iberian Peninsula during the Last Glacial Maximum and Mid-Holocene. Ecography, 30, 120-134. doi: 10.1111/j.2006.0906-7590.04813.x

Bonikowski, R., Celiński, K., Wojnicka-Półtorak, A., \& Maliński, T. (2015) Composition of essential oils isolated from the needles of $P$. uncinata Ramond ex. Mirb. and P. uliginosa Neumann ex Wimmer grown in Poland. Natural Product Communications, 10, 371-373.

Boratyńska, K., Boratyński, A., \& Lewandowski, A. (2003). Morphology of Pinus uliginosa (Pinaceae) needles from populations exposed to and isolated from the direct influence of Pinus sylvestris. Botanical Journal of the Linnean Society, 142, 83-91. doi: 10.1046/j.1095-8339.2003.00156.x 
Boratyńska, K., Dzialuk, A., Lewandowski, A., Marcysiak, K., Jasińska, A.K., Sobierajska, K., ... Boratyński, A. (2014). Geographic distribution of quantitative traits variation and genetic variability in natural populations of Pinus mugo in Central Europe. Dendrobiology, 72, 65-84. doi:

10.12657/denbio.072.006

Boratyńska, K., Jasińska, A. K., \& Boratyński, A. (2015). Taxonomic and geographic differentiation of Pinus mugo complex on the needle characteristics. Systematics and Biodiversity, 13, 581-595. doi: 10.1080/14772000.2015.1058300

Boratyńska, K., \& Lewandowska, D. (2009). Differences among three populations of Pinus uliginosa and their relation to $P$. sylvestris as expressed by the needle characters. Dendrobiology, 61, 37-46.

Boratyńska, K., Marcysiak, K., \& Boratyński, A. (2005). Pinus mugo (Pinaceae) in the Abruzzi Mountains: high morphological variation in isolated populations. Botanical Journal of the Linnean Society, 147, 309-316. doi: 10.1111/j.10958339.2005.00374.x

Boratyński, A., Boratyńska, K., Lewandowski, A., Gołąb, Z., \& Kiciński, P. (2003). Evidence of the possibility of natural reciprocal crosses between Pinus sylvestris and P. uliginosa based on the phenology of reproductive organs. Flora Morphology, Distribution, Functional Ecology of Plants, 198, 377-388. doi: $10.1078 / 0367-2530-00110$

Bucci, G., González-Martínez, S.C., Le Provost, G., Plomion, C., Ribeiro, M.M., Sebastiani, F., ... Vendramin, G.G. (2007). Range-wide phylogeography and gene zones in Pinus pinaster Ait. revealed by chloroplast microsatellite markers. Molecular Ecology, 16, 2137-2153. doi: 10.1111/j.1365-294X.2007.03275.x 
Burczyk, J., \& Chalupka, W. (1997). Flowering and cone production variability and its effect on parental balance in a Scots pine clonal seed orchard. Annales Des Sciences Forestières, 54, 129-144. doi: 10.1051/forest:19970201

Burga, C. A. (1988). Swiss vegetation history during the Last 18000 Years. New Phytologist, 110, 581-602.

Businsky, R., \& Kirschner, J. (2006). Nomenclatural notes on the Pinus mugo complex in central Europe. Phyton, 46, 129-139.

Celiński, K., Bonikowski, R., Wojnicka-Półtorak, A., Chudzińska, E., \& Maliński, T. (2015) Volatiles as chemosystematic markers for distinguishing closely related species within the Pinus mugo complex. Chemistry and Biodiversity 12, 12081213. doi: $10.1002 / \mathrm{cbdv} .201400253$

Celiński, K., Pawlaczyk, E. M., Wojnicka-Półtorak, A., Chudzińska, E., \& PrusGłowacki, W. (2013). Cross-species amplification and characterization of microsatellite loci in Pinus mugo Turra. Biologia, 68, 621-626. doi: $10.2478 / \mathrm{s} 11756-013-0189-\mathrm{Z}$

Celiński, K., Zbránková, V., Wojnicka-Półtorak, A., \& Chudzińska, E. (2015). Biogeography and evolutionary factors determine genetic differentiation of Pinus mugo (Turra) in the Tatra Mountains (Central Europe). Journal of Mountain Science, 12, 549-557. doi: 10.1007/s11629-014-3028-y

Chakraborty, R., \& Jin, L. (1993). Determination of relatedness between individuals using DNA fingerprinting. Human Biology, 65, 875-895.

Cheddadi, R., Birks, H. J. B., Tarroso, P., Liepelt, S., Gömöry, D., Dullinger, S., ... Laborde, H. (2013). Revisiting tree-migration rates: Abies alba (Mill.), a case study. Vegetation History and Archaeobotany, 23, 113-122. doi:

$10.1007 / \mathrm{s} 00334-013-0404-4$ 
Christensen, K. I. (1987). Taxonomic revision of the Pinus mugo complex and $P$. rhaetica $($ P. mugo $\times$ sylvestris) (Pinaceae). Nordic Journal of Botany, 7, 383408. doi: 10.1111/j.1756-1051.1987.tb00958.x

Corander, J., Waldmann, P., \& Sillanpää, M. J. (2003). Bayesian analysis of genetic differentiation between populations. Genetics, 163, 367-374.

de Beaulieu, J.-L., Andrieu-Ponel, V., Reille, M., Grüger, E., Tzedakis, C., \& Svobodova, H. (2001). An attempt at correlation between the Velay pollen sequence and the Middle Pleistocene stratigraphy from central Europe. Quaternary Science Reviews, 20, 1593-1602. doi: 10.1016/S02773791(01)00027-0

Danusevičius, D., Buchovska, J., Stanys, V., Šikšnianienė, J. B., Baliuckas, V., \& Brazaitis, G. (2012). Chloroplast DNA polymorphism of an exotic $P$. mugo Turra population introduced to seaside spit of Kursiu Nerija in Lithuania. European Journal of Forest Research, 132, 137-150. doi: 10.1007/s10342-0120663-0

Danusevičius, D., Buchovska, J., Stanys, V., Šikšnianienè, J. B., Marozas, V., \& Bendokas, V. (2013). DNA marker based identification of spontaneous hybrids between Pinus mugo and P. sylvestris at the Lithuanian sea-side. Nordic Journal of Botany, 31, 344-352. doi: 10.1111/j.1756-1051.2012.01575.x

Dering, M., Misiorny, A., Lewandowski, A., \& Korczyk, A. (2011). Genetic and historical studies on the origin of Norway spruce in Białowieża Primeval Forest in Poland. European Journal of Forest Research, 131, 381-387. doi: $10.1007 / \mathrm{s} 10342-011-0510-8$ 
Doyle, J. J., \& Doyle, J. L. (1990). Isolation of plant DNA from fresh tissue. Focus, 12, $13-15$.

Dzialuk, A., Boratyński, A., Boratyńska, K., \& Burczyk, J. (2012). Geographic patterns of genetic diversity of Pinus mugo (Pinaceae) in Central European mountains. Dendrobiology, 68, 31-41.

Dzialuk, A., Chybicki, I., Gout, R., Mączka, T., Fleischer, P., Konrad, H., ... Valadon, A. (2014). No reduction in genetic diversity of Swiss stone pine (Pinus cembra L.) in Tatra Mountains despite of high fragmentation and small population size: implications for management and conservation of timberline ecotone. Conservation Genetics 15,1433-1445. doi:10.1007/s10592-014-0628-6

Dzialuk, A., Muchewicz, E., Boratyński, A., Montserrat, J. M., Boratyńska, K., \& Burczyk, J. (2009). Genetic variation of Pinus uncinata (Pinaceae) in the Pyrenees determined with cpSSR markers. Plant Systematics and Evolution, 277, 197-205. doi: 10.1007/s00606-008-0123-y

Ellenberg, H. (1996). Vegetation Mitteleuropas mit den Alpen in ökologischer, dynamischer und historischer Sicht. Stuttgart: Ulmer. ISBN 3-8252-8104-3.

Ellstrand, N. C., \& Roose, M. L. (1987). Patterns of genotypic diversity in clonal plant species. American Journal of Botany, 74, 123-131. doi: 10.2307/2444338

Estoup, A., Jarne, P., \& Cornuet, J.-M. (2002). Homoplasy and mutation model at microsatellite loci and their consequences for population genetics analysis. Molecular Ecology, 11, 1591-1604. doi: 10.1046/j.1365-294X.2002.01576.x

Excoffier, L., \& Lischer, H. E. L. (2010). Arlequin suite ver 3.5: a new series of programs to perform population genetics analyses under Linux and Windows. 
Molecular Ecology Resources, 10, 564-567. doi: 10.1111/j.17550998.2010.02847.x

Fauvart, N., Ali, A. A., Terral, J.-F., Roiron, P., Blarquez, O., \& Carcaillet, C. (2012). Holocene upper tree-limits of Pinus section sylvestris in the Western Alps as evidenced from travertine archives. Review of Palaeobotany and Palynology, 169, 96-102. doi: 10.1016/j.revpalbo.2011.10.003

Felsenstein, J. (1989). PHYLIP - Phylogeny Inference Package (Version 3.2). Cladistics, 5, 164-166.

Goldstein, D. B., Linares, A. R., Cavalli-Sforza, L. L., \& Feldman, M. W. (1995). An evaluation of genetic distances for use with microsatellite loci. Genetics, 139, $463-471$.

Gómez, A., Vendramin, G. G., González-Martínez, S. C., \& Alía, R. (2005). Genetic diversity and differentiation of two Mediterranean pines (Pinus halepensis Mill. and Pinus pinaster Ait.) along a latitudinal cline using chloroplast microsatellite markers. Diversity and Distributions, 11, 257-263. doi: 10.1111/j.13669516.2005.00152.x

Gömöry, D., Longauer, R., Paule, L., Krajmerová, D., \& Schmidtová, J. (2010). Acrossspecies patterns of genetic variation in forest trees of Central Europe. Biodiversity and Conservation, 19, 2025-2038. doi: 10.1007/s10531-010-9823-z

Gömöry, D., Paule, L., Krajmerová, D., Romšáková, I., \& Longauer, R. (2012). Admixture of genetic lineages of different glacial origin: a case study of Abies alba Mill. in the Carpathians. Plant Systematics and Evolution, 298, 703-712. doi: 10.1007/s00606-011-0580-6 
Hamerník, J., \& Musil, I. (2007). The Pinus mugo complex - Its structuring and general overview of the used nomenclature. Journal of Forest Science, 53, 253-266.

Hammer, Ø., Harper, D. A. T., \& Ryan, P. D. (2001). Past: Paleontological statistics software package for education and data analysis. Palaeontologia Electronica, 4, XIX-XX.

Hardy, O. J., Charbonnel, N., Fréville, H., \& Heuertz, M. (2003). Microsatellite allele sizes: a simple test to assess their significance on genetic differentiation. Genetics, 163, 1467-1482.

Hardy, O. J., \& Vekemans, X. (2002). SPAGeDi: a versatile computer program to analyse spatial genetic structure at the individual or population levels. Molecular Ecology Notes, 2, 618-620. doi: 10.1046/j.1471-8286.2002.00305.x

Heuertz, M., Teufel, J., González-Martínez, S. C., Soto, A., Fady, B., Alía, R., \& Vendramin, G. G. (2010). Geography determines genetic relationships between species of mountain pine (Pinus mugo complex) in western Europe. Journal of Biogeography, 37, 541-556. doi: 10.1111/j.1365-2699.2009.02223.x

Hewitt, G. M. (2004). Genetic consequences of climatic oscillations in the Quaternary. Philosophical Transactions of the Royal Society B: Biological Sciences, 359, $183-195$.

Hewitt, G. M., \& Godfrey, M. (1996). Some genetic consequences of ice ages, and their role in divergence and speciation. Biological Journal of the Linnean Society, 58, 247-276. doi: 10.1006/bij1.1996.0035

Höhn, M., Gugerli, F., Abran, P., Bisztray, G., Buonamici, A., Cseke, ... Vendramin, G.G. (2009). Variation in the chloroplast DNA of Swiss stone pine (Pinus cembra L.) reflects contrasting post-glacial history of populations from the 
Carpathians and the Alps. Journal of Biogeography, 36, 1798-1806. doi: $10.1111 / \mathrm{j} .1365-2699.2009 .02122 . \mathrm{x}$

Jalas, J., \& Suominen, J. (eds.). (1973). Atlas Florae Europaeae: distribution of vascular plants in Europe. 2: Gymnospermae (Pinaceae to Ephedraceae). Helsinki: Akateeminen Kirjakaupa. ISBN 951-9108-01-7

Jankovská, V. (2008). Slovenské a moravské Karpaty v poslední době ledové - ostrov “sibiřské tajgy" v Evropě [Slovak and Moravien Carpathians in the last glacial period - as island of Siberian taiga in Europe]. Phytopedon, 7, 1336-1120.

Jasińska, A. K., Wachowiak, W., Muchewicz, E., Boratyńska, K., Montserrat, J. M., \& Boratyński, A. (2010). Cryptic hybrids between Pinus uncinata and P. sylvestris. Botanical Journal of the Linnean Society, 163, 473-485. doi: 10.1111/j.10958339.2010.01065.x

Kalinowski, S. T. (2005). hp-rare 1.0: a computer program for performing rarefaction on measures of allelic richness. Molecular Ecology Notes, 5, 187-189. doi: $10.1111 / \mathrm{j} .1471-8286.2004 .00845 . \mathrm{x}$

Kalinowski, S. T. (2009). How well do evolutionary trees describe genetic relationships among populations? Heredity, 102, 506-513. doi: 10.1038/hdy.2008.136

Karhu, A., Hurme, P., Karjalainen, M., Karvonen, P., Kärkkäinen, K., Neale, D., \& Savolainen, O. (1996). Do molecular markers reflect patterns of differentiation in adaptive traits of conifers? Theoretical and Applied Genetics, 93, 215-221. doi: 10.1007/BF00225748

Kurt, Y., González-Martínez, S. C., Alía, R., \& Isik, K. (2011). Genetic differentiation in Pinus brutia Ten. using molecular markers and quantitative traits: the role of 
altitude. Annals of Forest Science, 69, 345-351. doi: 10.1007/s13595-011-0169-

9

Latałowa, M., Tobolski, K., \& Nalepka, D. (2004). Pinus L. subgenus Pinus (subgen. Diploxylon (Koehne) Pilger). In: M. Ralska-Jasiewiczowa, M. Latalowa, K. Wasylikowa, K. Tobolski, E. Madeyska, H. E. Wright jr., ... A. Walanus (Eds.), Late glacial and holocene history of vegetation in Poland based on isopollen maps (pp. 165-177). Krakow: W. Szafer Institute of Botany.

Lendvay, B., Höhn, M., Brodbeck, S., Mîndrescu, M., \& Gugerli, F. (2014). Genetic structure in Pinus cembra from the Carpathian Mountains inferred from nuclear and chloroplast microsatellites confirms post-glacial range contraction and identifies introduced individuals. Tree Genetics \& Genomes, 10, 1419-1433. doi: 10.1007/s11295-014-0770-9

Lewandowski, A., Boratyński, A., \& Mejnartowicz, L. (2000). Allozyme investigations on the genetic differentiation between closely related pines - Pinus sylvestris, P. mugo, P. uncinata and P. uliginosa (Pinaceae). Plant Systematics and Evolution, 221, 15-24. doi: 10.1007/BF01086377

Lewandowski, A., Samoćko, J., Boratyńska, K., \& Boratyński, A. (2002). Genetic differences between two Polish populations of Pinus uliginosa, compared to $P$. sylvestris and P. mugo. Dendrobiology, 48, 51-57.

Liepelt, S., Cheddadi, R., de Beaulieu, J.-L., Fady, B., Gömöry, D., Hussendörfer, ... Ziegenhagen, B. (2009). Postglacial range expansion and its genetic imprints in Abies alba (Mill.) - a synthesis from palaeobotanic and genetic data. Review of Palaeobotany and Palynology, 153, 139-149. doi:

10.1016/j.revpalbo.2008.07.007 
Liu, K., \& Muse, S. V. (2005). PowerMarker: an integrated analysis environment for genetic marker analysis. Bioinformatics, 21, 2128-2129. doi:

10.1093/bioinformatics/bti282

Magri, D., Vendramin, G.G., Comps, B., Dupanloup, I., Geburek, T., Gömöry, D., ... De Beaulieu, J.-L., (2006). A new scenario for the Quaternary history of European beech populations: palaeobotanical evidence and genetic consequences. New Phytologist, 171, 199-221. doi: 10.1111/j.14698137.2006.01740.x

Magyari, E. K., Jakab, G., Bálint, M., Kern, Z., Buczkó, K., \& Braun, M. (2012). Rapid vegetation response to Lateglacial and early Holocene climatic fluctuation in the South Carpathian Mountains (Romania). Quaternary Science Reviews, 35, 116130. doi: 10.1016/j.quascirev.2012.01.006

Monteleone, I., Ferrazzini, D., \& Belletti, P. (2006). Effectiveness of neutral RAPD markers to detect genetic divergence between the subspecies uncinata and mugo of Pinus mugo Turra. Silva Fennica, 40, 391-406. doi: 10.14214/sf.476

Mosca, E., Eckert, A. J., Di Pierro, E. A., Rocchini, D., La Porta, N., Belletti, P., \& Neale, D. B. (2012). The geographical and environmental determinants of genetic diversity for four alpine conifers of the European Alps. Molecular Ecology, 21, 5530-5545. doi: 10.1111/mec.12043

Muona, O., \& Harju, A. (1989). Effective population sizes, genetic variability, and mating system in natural stands and seed orchards of Pinus sylvestris. Silvae Genetica, 38, 221-228. 
Neale, D. B., \& Sederoff, R. R. (1989). Paternal inheritance of chloroplast DNA and maternal inheritance of mitochondrial DNA in loblolly pine. Theoretical and Applied Genetics, 77(2). doi: 10.1007/BF00266189

Nei, M., Tajima, F., \& Tateno, Y. (1983). Accuracy of estimated phylogenetic trees from molecular data. Journal of Molecular Evolution, 19, 153-170. doi: 10.1007/BF02300753

Obidowicz, A. (1996). A late Glacial-Holocene history of the formation of vegetation belts in the Tatra Mts. Acta Palaeobotanica, 36, 159-206.

Ozenda, P. (1988). Die Vegetation der Alpen im europäischen Gebirgsraum. München: Elsevier. ISBN 978-3437203947

Peakall, R., \& Smouse, P. E. (2006). genalex 6: genetic analysis in Excel. Population genetic software for teaching and research. Molecular Ecology Notes, 6, 288295. doi: 10.1111/j.1471-8286.2005.01155.x

Petit, R. J. (2003). Glacial refugia: hotspots but not melting pots of genetic diversity. Science, 300, 1563-1565. doi: 10.1126/science.1083264

Pluess, A. R. (2011). Pursuing glacier retreat: genetic structure of a rapidly expanding Larix decidua population. Molecular Ecology, 20, 473-485. doi: 10.1111/j.1365-294X.2010.04972.x

Powell, W., Morgante, M., McDevitt, R., Vendramin, G. G., \& Rafalski, J. A. (1995). Polymorphic simple sequence repeat regions in chloroplast genomes: applications to the population genetics of pines. Proceedings of the National Academy of Sciences of the United States of America, 92, 7759-7763. 
Provan, J., \& Bennett, K. D. (2008). Phylogeographic insights into cryptic glacial refugia. Trends in Ecology \& Evolution, 23, 564-571. doi:

10.1016/j.tree.2008.06.010

Provan, J., Powell, W., \& Hollingsworth, P. M. (2001). Chloroplast microsatellites: new tools for studies in plant ecology and evolution. Trends in Ecology \& Evolution, 16, 142-147. doi: 10.1016/S0169-5347(00)02097-8

Provan, J., Soranzo, N., Wilson, N. J., McNicol, J. W., Forrest, G. I., Cottrell, J., \& Powell, W. (1998). Gene-pool variation in Caledonian and European Scots pine (Pinus sylvestris L.) revealed by chloroplast simple-sequence repeats. Proceedings of the Royal Society B: Biological Sciences, 265, 1697-1705.

Prus-Głowacki, W., Bajus, E., \& Ratyńska, H. (1998). Taxonomic position of Pinus uliginosa Neumann as related to other taxa of Pinus mugo complex. Acta Societatis Botanicorum Poloniae, 67, 269-274. doi: 10.5586/asbp.1998.035

Pyhäjärvi, T., Salmela, M. J., \& Savolainen, O. (2007). Colonization routes of Pinus sylvestris inferred from distribution of mitochondrial DNA variation. Tree Genetics \& Genomes, 4, 247-254. doi: 10.1007/s11295-007-0105-1

Ribeiro, M. M., Plomion, C., Petit, R., Vendramin, G. G., \& Szmidt, A. E. (2001). Variation in chloroplast single-sequence repeats in Portuguese maritime pine (Pinus pinaster Ait.). Theoretical and Applied Genetics, 102, 97-103. doi: $10.1007 / \mathrm{s} 001220051623$

Robledo-Arnuncio, J. J., Collada, C., Alía, R., \& Gil, L. (2005). Genetic structure of montane isolates of Pinus sylvestris L. in a Mediterranean refugial area. Journal of Biogeography, 32, 595-605. doi: 10.1111/j.1365-2699.2004.01196.x 
Ronikier, M. (2011). Biogeography of high-mountain plants in the Carpathians: An emerging phylogeographical perspective. Taxon, 60, 373-389.

Sannikov, S. N., Petrova, I. V., Schweingruber, F., Egorov, E. V., \& Parpan, T. V. (2011). Genetic differentiation of Pinus mugo Turra and P. sylvestris L. populations in the Ukrainian Carpathians and the Swiss Alps. Russian Journal of Ecology, 42, 270-276. doi: 10.1134/S1067413611040151

Savolainen, O., Pyhäjärvi, T., \& Knürr, T. (2007). Gene flow and local adaptation in trees. Annual Review of Ecology, Evolution, and Systematics, 38, 595-619. doi: 10.1146/annurev.ecolsys.38.091206.095646

Slavov, G. T., \& Zhelev, P. (2004). Allozyme variation, differentiation, and inbreeding in populations of Pinus mugo in Bulgaria. Canadian Journal of Forest Research, 34, 2611-2617. doi: 10.1139/x04-127

Smouse, P. E., Dyer, R. J., Westfall, R. D., \& Sork, V. L. (2001). Two-generation analysis of pollen flow across a landscape. I. Male gamete heterogeneity among females. Evolution, 55, 260-271.

Stachurska-Swakoń, A., Cieślak, E., \& Ronikier, M. (2013). Phylogeography of a subalpine tall-herb Ranunculus platanifolius (Ranunculaceae) reveals two main genetic lineages in the European mountains. Botanical Journal of the Linnean Society, 171, 413-428. doi: 10.1111/j.1095-8339.2012.01323.x

Staszkiewicz, J., \& Tyszkiewicz, M. (1976). Zmienność populacyjna i osobnicza szyszek kosodrzewiny (Pinus mugo Turra) ze szczególnym uwzględnieniem materiałów z Karpat [Population and individual variability of cones of dwarf mountain pine (Pinus mugo Turra) with special regard to materials from Carpathians]. Fragmenta Flortistica et Geobotanica, 22, 19-29. 
Taberlet, P., Fumagalli, L., Wust-Saucy, A.-G., \& Cosson, J.-F. (1998). Comparative phylogeography and postglacial colonization routes in Europe. Molecular Ecology, 7, 453-464. doi: 10.1046/j.1365-294x.1998.00289.x

Temunović, M., Franjić, J., Satovic, Z., Grgurev, M., Frascaria-Lacoste, N., \& Fernández-Manjarrés, J. F. (2012). Environmental Heterogeneity Explains the Genetic Structure of Continental and Mediterranean Populations of Fraxinus angustifolia Vahl. PLOS ONE, 7, e42764. doi: 10.1371/journal.pone.0042764

Thiel-Egenter, C., Alvarez, N., Holderegger, R., Tribsch, A., Englisch, T., Wohlgemuth, T., ... Gugerli, F. (2011). Break zones in the distributions of alleles and species in alpine plants. Journal of Biogeography, 38, 772-782. doi: 10.1111/j.13652699.2010.02441.x

Tsaryk, I., Didukh, Y. P., Tasenkevich, L., Waldon, B., \& Boratyński, A. (2006). Pinus mugo Turra (Pinaceae) in the Ukrainian Carpathians. Dendrobiology, 55, 39-49.

Vendramin, G. G., Anzidei, M., Madaghiele, A., \& Bucci, G. (1998). Distribution of genetic diversity in Pinus pinaster Ait. as revealed by chloroplast microsatellites. Theoretical and Applied Genetics, 97, 456-463. doi: $10.1007 / \mathrm{s} 001220050917$

Vendramin, G. G., Lelli, L., Rossi, P., \& Morgante, M. (1996). A set of primers for the amplification of 20 chloroplast microsatellites in Pinaceae. Molecular Ecology, 5, 595-598. doi: 10.1111/j.1365-294X.1996.tb00353.x

Villar, L., Sesé, J. A., Franco, J. A. S., \& Ferrández, J. V. (1997). Atlas de la flora del Pirineo Aragonés. Vol. 1. Huesca: Consejo de Protección de la Naturaleza de Aragón. ISBN 84-89862-04-1 
Wachowiak, W., Boratyńska, K., \& Cavers, S. (2013). Geographical patterns of nucleotide diversity and population differentiation in three closely related European pine species in the Pinus mugo complex. Botanical Journal of the Linnean Society, 172, 225-238. doi: 10.1111/boj.12049

Wachowiak, W., Cavers, S., \& Żukowska, W. B. (2015). Interspecific gene flow and ecological selection in a pine (Pinus sp.) contact zone. Plant Systematics and Evolution, 301, 1643-1652. doi: 10.1007/s00606-014-1182-x

Wachowiak, W., Palmé, A. E., \& Savolainen, O. (2011). Speciation history of three closely related pines Pinus mugo (T.), P. uliginosa (N.) and P. sylvestris (L.). Molecular Ecology, 20, 1729-1743. doi: 10.1111/j.1365-294X.2011.05037.x

Wachowiak, W., \& Prus-Głowacki, W. (2009). Different patterns of genetic structure of relict and isolated populations of endangered peat-bog pine (Pinus uliginosa Neumann). Journal of Applied Genetics, 50, 329-339. doi:

10.1007/BF03195691

Wachowiak, W., Żukowska, W. B., Wójkiewicz, B., Cavers, S., \& Litkowiec, M. (2016). Hybridization in contact zone between temperate European pine species. Tree Genetics \& Genomes, 12, 48. doi: 10.1007/s11295-016-1007-x

Wohlfarth, B., Hannon, G., Feurdean, A., Ghergari, L., Onac, B. P., \& Possnert, G. (2001). Reconstruction of climatic and environmental changes in NW Romania during the early part of the last deglaciation $(\sim 15,000-13,600$ cal yr BP). Quaternary Science Reviews, 20, 1897-1914. doi: 10.1016/S02773791(01)00014-2

Wojnicka-Półtorak, A., Celiński, K., Chudzińska, E., Prus-Głowacki, W., \& Niemtur, S. (2015) Genetic resources of Pinus cembra L. marginal populations from the 
Tatra Mountains: Implications for conservation. Biochemical Genetics 53, 49-

61.

Wright, S. (1965). The interpretation of population structure by $F$-statistics with special regard to systems of mating. Evolution, 19, 395-420. doi: 10.2307/2406450

Zarzycki, K., Trzcińska-Tacik, H., Różański, W., Szeląg, Z., Wołek, J., \& Korzeniak, U. (2002). Ecological Indicator Values of Vascular Plants of Poland. In: Z. Mirek (Ed.), Biodiversity of Poland (pp. 1-183). Kraków: W. Szafer Institute of Botany, Polish Academy of Sciences. 
Figure captions

Fig. 1 The taxa of Pinus mugo complex (P. mugo s.1.) investigated: a) dwarf mountain pine P. mugo Turra $=$ P. mugo s.s. $[$ P. mugo subsp. mugo (Turra) Christensen] in the Sudetes, b) mountain pine - P. uncinata Ramond [P. mugo subsp. uncinata (Ramond.) Christensen] in the Pyrenees, c) peat-bog pine - P. uliginosa Naumann in the Sudetes (photo by A. Boratyński)

Fig. 2 Relationship between geographic distance and the pairwise $F_{S T}$ (isolation by distance analysis) in the P. mugo s.l. and particular taxa of the P. mugo complex

Fig. 3 Results of spatial (big dots) and non-spatial Bayesian cluster analysis (inside dots), BAPS, showing genetically homogenous groups of populations of the Pinus mugo complex. Colours indicate nine $(\mathrm{K}=9)$ and eight clusters $(\mathrm{K}=8)$, respectively. Geographic range of Pinus mugo s.l. taxa [20, simplified]. Acronyms as in Table 1 (first letters denote: $\mathrm{M}-P$. mugo s.s., $\mathrm{U}-P$. uncinata, $\mathrm{UL}-P$. uliginosa).

Fig. 4 Genetic relatedness among populations of $P$. mugo s.1 using: 1 - shared allele distance $D_{S A}$ and cluster analysis via the neighbor joining method, with relative strength of the nodes determined using bootstrapping analysis, the numbers indicate strength of node more than $50 \%, \mathrm{R}^{2}$ describes how well a tree fit the genetic data; 2 - geographical location of the clusters; 3 - the principal coordinate analysis (PCoA) based on Nei's genetic distances between populations; 4 - the principal coordinate analysis (PCoA) based on Nei's genetic distances between P. mugo s.s., P. uncinata and P. uliginosa.

Fig. 5 Putative gene exchange between populations of the P. mugo complex during glacial periods based on data from microsatellite markers in chloroplast DNA 

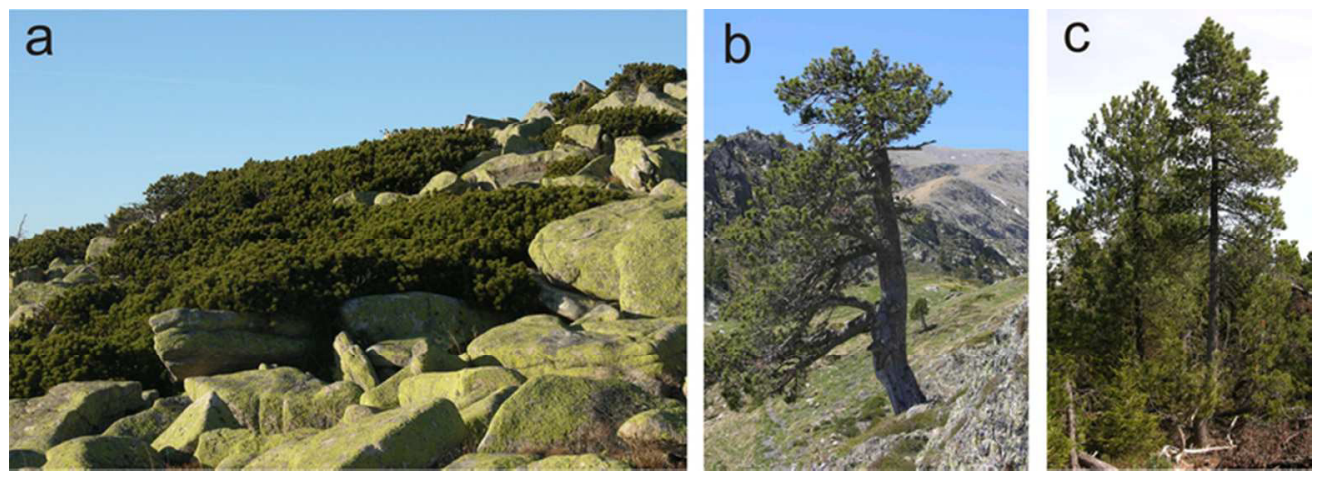

Fig. 1

$71 \times 25 \mathrm{~mm}(300 \times 300$ DPI $)$ 


\section{Page 43 of 53}
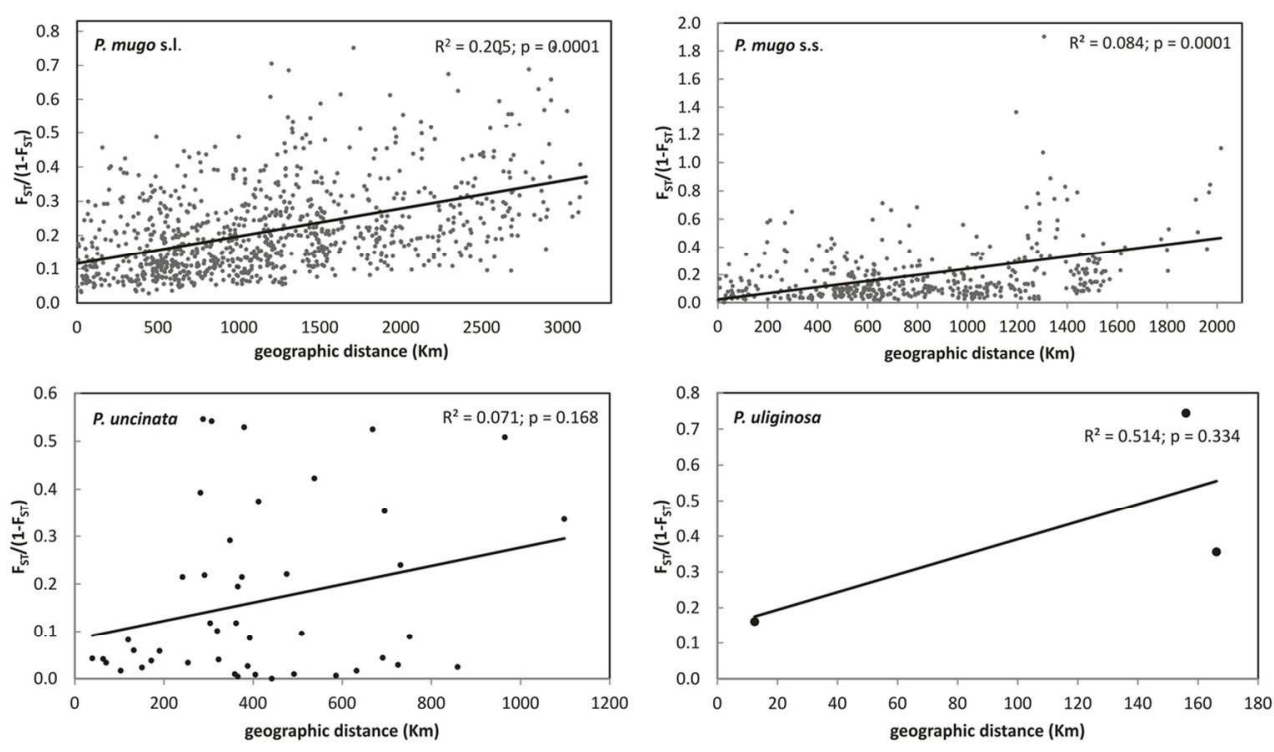

Fig. 2

$113 \times 66 \mathrm{~mm}(300 \times 300$ DPI) 


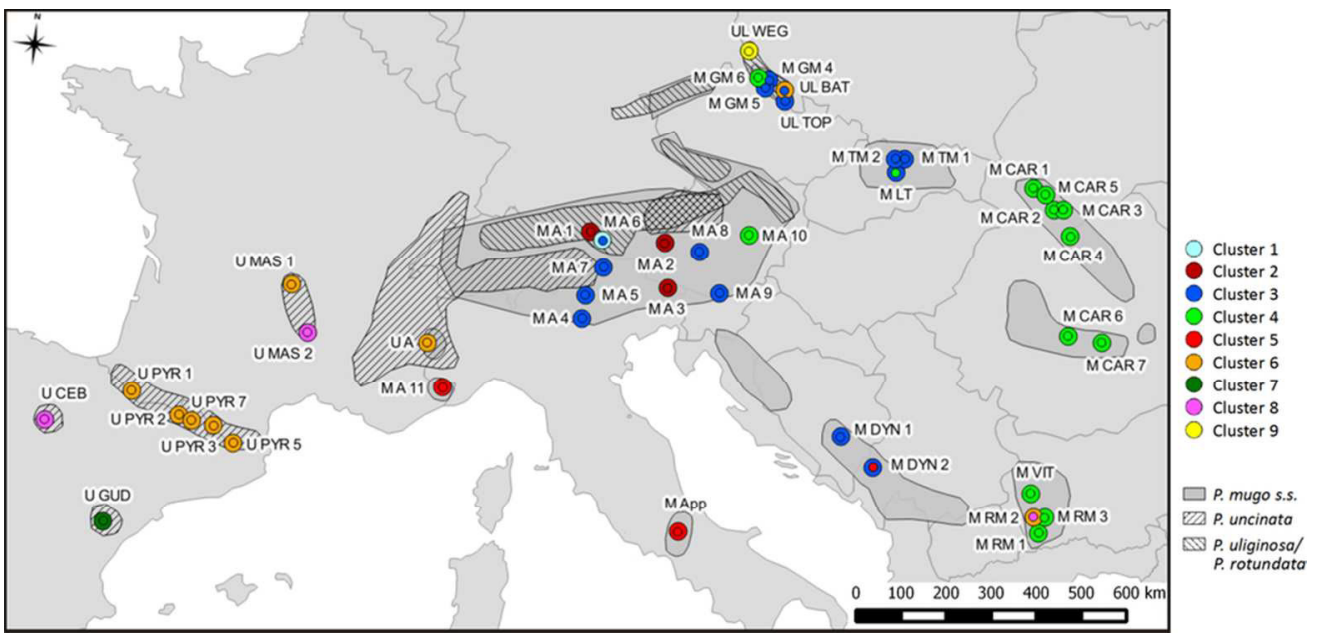

Fig. 3

$83 \times 40 \mathrm{~mm}(300 \times 300$ DPI $)$ 


\section{Page 45 of 53}

1

2

3

4

5

6

7

8

9

10

11

12

13

14

15

16

17

18

19

20

21

22

23

24

25

26

27

28

29

30

31

32

33

34

35

36

37

38

39

40

41

42

43

44

45

46

47

48

49

50

51

52

53

54

55

56

57

58

59

60

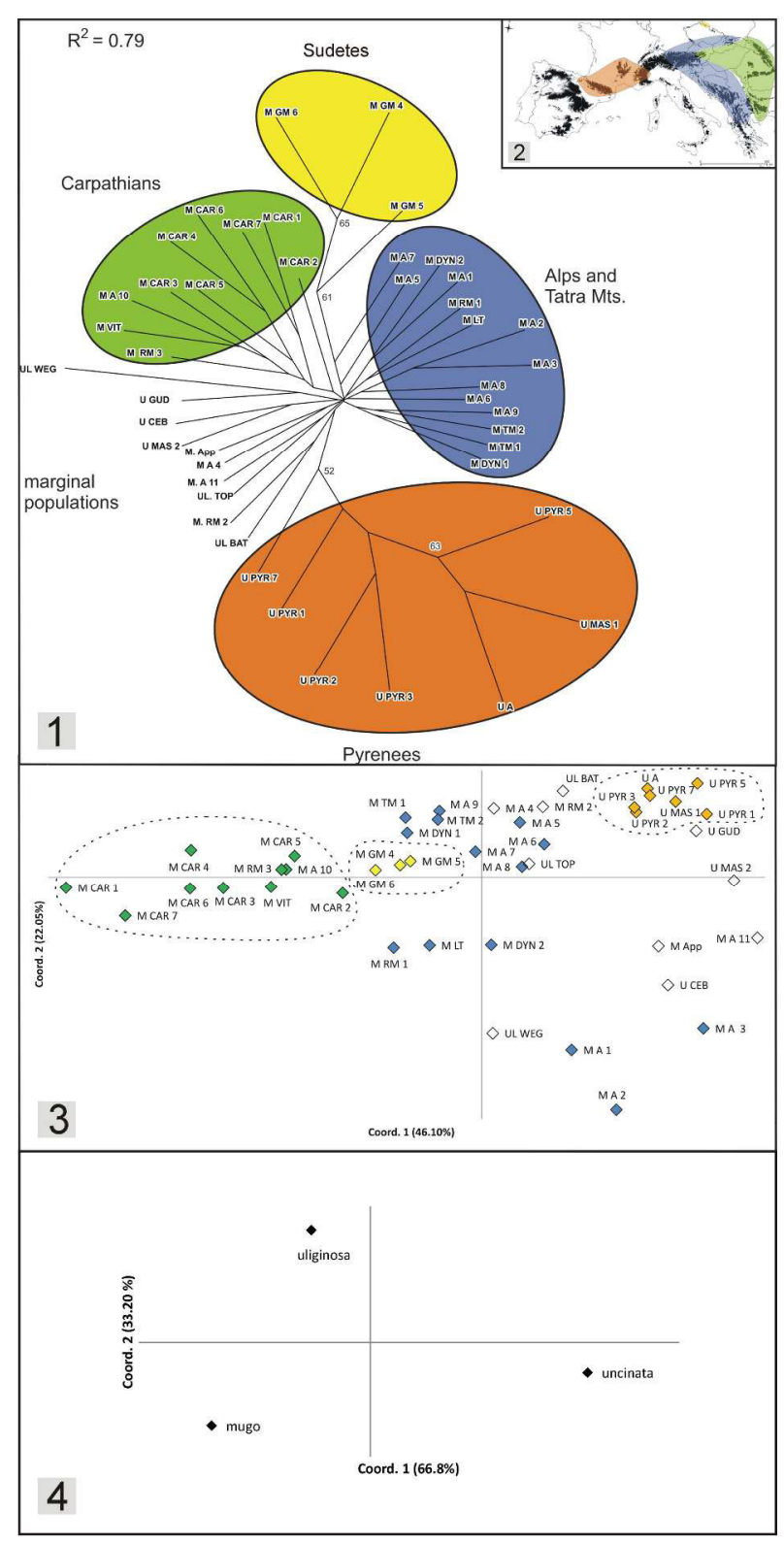

Fig. 4

$227 \times 448 \mathrm{~mm}(300 \times 300$ DPI $)$ 


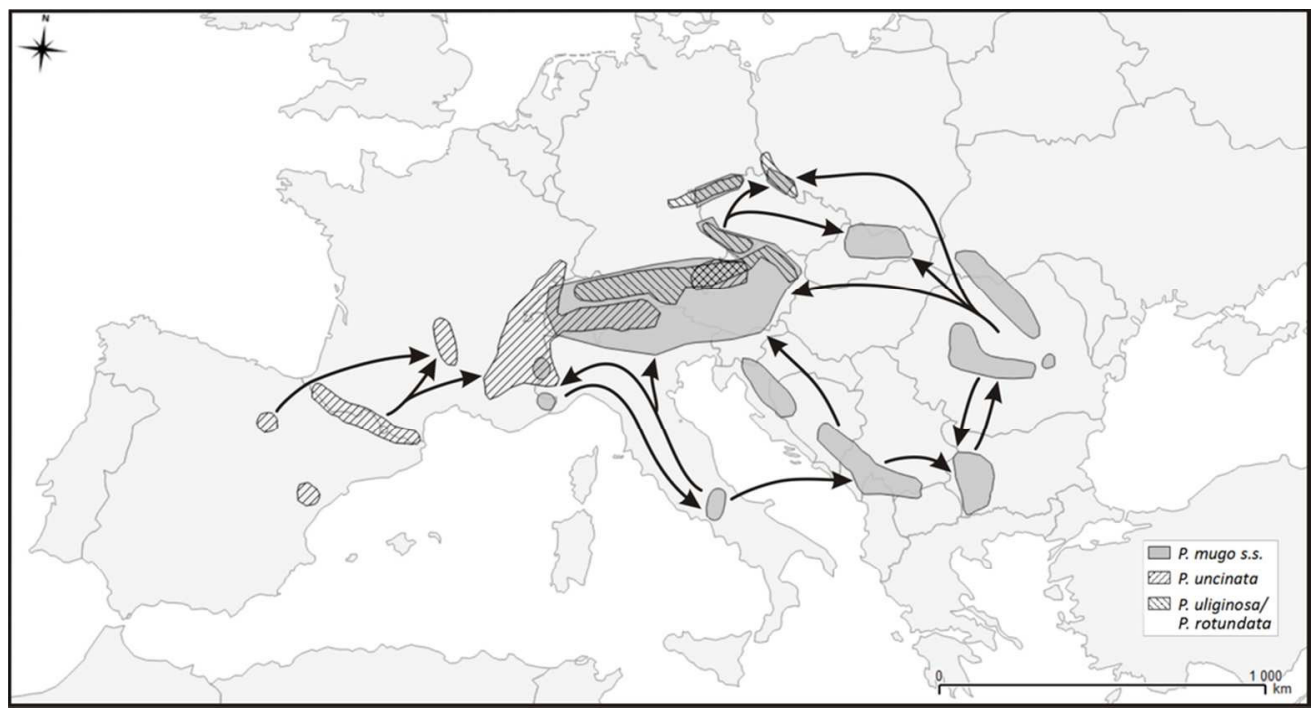

Fig. 5

$93 \times 50 \mathrm{~mm}(300 \times 300 \mathrm{DPI})$ 
Table 1 Geographical characteristics of the P. mugo s.s., P. uncinata and P. uliginosa populations

\begin{tabular}{|c|c|c|c|c|c|c|}
\hline Taxon & Label & Region & Locality & $\begin{array}{c}\text { Latitude /Longitude } \\
{\left[{ }^{\circ}\right]}\end{array}$ & $\begin{array}{c}\text { Elevation } \\
{[\mathrm{m}]}\end{array}$ & Data source \\
\hline \multirow[t]{32}{*}{ mugo s.s } & M A 1 & $\begin{array}{l}\text { E Alps, Bavarian Alpen } \\
\text { (Germany) }\end{array}$ & $\begin{array}{l}\text { Ammergauer } \\
\text { Kreuzspitze }\end{array}$ & $47.53 \mathrm{~N} / 10.92 \mathrm{E}$ & 1800 & $\begin{array}{l}\text { Dzialuk et al. 2012; } \\
\text { Boratyńska et al., } 2014\end{array}$ \\
\hline & M A 2 & $\begin{array}{l}\text { E Alps, Salzburgische Alpen } \\
\text { (Austria) }\end{array}$ & Hochkonig & $47.43 \mathrm{~N} / 13.08 \mathrm{E}$ & 1800 & $\begin{array}{l}\text { Dzialuk et al. 2012; } \\
\text { Boratyńska et al., } 2014\end{array}$ \\
\hline & M A 3 & E Alps, Karnische Alpen (Italy) & Passo di Pramollo & $46.55 \mathrm{~N} / 13.26 \mathrm{E}$ & 1530 & $\begin{array}{l}\text { Dzialuk et al. 2012; } \\
\text { Boratyńska et al., } 2014\end{array}$ \\
\hline & M A 4 & E Alps, Prealpi Venete (Italy) & Monte Baldo, & $45.81 \mathrm{~N} / 10.94 \mathrm{E}$ & 1750 & \\
\hline & M A 5 & $\begin{array}{l}\text { Alpi Orientale, Gruppo di Brenta } \\
\text { (Italy) }\end{array}$ & Lago di Tovel & $46.27 \mathrm{~N} / 10.97 \mathrm{E}$ & 1200 & \\
\hline & M A 6 & $\begin{array}{l}\text { E Alps, Karwendel Gebirge } \\
\text { (Austria) }\end{array}$ & Scharnitz, above Isar & $47.38 \mathrm{~N} / 11.30 \mathrm{E}$ & 1400 & \\
\hline & M A 7 & West Alps, Sarntaler Alpen (Italy) & Passo di Penser Joch & $46.85 \mathrm{~N} / 11.40 \mathrm{E}$ & 1900 & \\
\hline & M A 8 & $\begin{array}{l}\text { E Alps, Schlaudminger Tauern } \\
\text { (Austria) }\end{array}$ & Negleck above Solkpass & $47.31 \mathrm{~N} / 14.10 \mathrm{E}$ & 1900 & \\
\hline & M A 9 & E Alps, Savinj Alpi (Slovenia) & Kamniška Bistrica & $46.51 \mathrm{~N} / 14.74 \mathrm{E}$ & 1600 & \\
\hline & M A 10 & $\begin{array}{l}\text { E Alps, Steirische Kalkalpen } \\
\text { (Austria) }\end{array}$ & Turntaler-Kg & $47.69 \mathrm{~N} / 15.49 \mathrm{E}$ & 1600 & \\
\hline & M A 11 & W Alps, Maritime Alps (Italy) & Coll de Tende & $44.13 \mathrm{~N} / 7.38 \mathrm{E}$ & 2000 & \\
\hline & M APP & Appenines (Italy) & Abruzzi, La Maiella & $41.77 \mathrm{~N} / 13.98 \mathrm{E}$ & 2200 & \\
\hline & M CAR 1 & E Carpathians, Gorgany (Ukraine) & Kanch Mt near Synevir & $48.55 \mathrm{~N} / 23.83 \mathrm{E}$ & 1550 & \\
\hline & M CAR 2 & $\begin{array}{l}\text { E Carpathians, Chornokhora } \\
\text { (Ukraine) }\end{array}$ & Breskulec & $48.11 \mathrm{~N} / 24.58 \mathrm{E}$ & 1650 & \\
\hline & M CAR 3 & $\begin{array}{l}\text { E Carpathians, Chornokhora } \\
\text { (Ukraine) }\end{array}$ & Pozhyzhevska & $48.09 \mathrm{~N} / 24.66 \mathrm{E}$ & 1700 & \\
\hline & M CAR 4 & E Carpathians, Rodna (Romania) & Borsa, Prislop, & $47.57 \mathrm{~N} / 24.80 \mathrm{E}$ & 1750 & \\
\hline & M CAR 5 & E Carpathians, Gorgan (Ukraine) & Gorgany Nature Reserve & $48.41 \mathrm{~N} / 24.17 \mathrm{E}$ & 1300 & \\
\hline & M CAR 6 & S Carpathians, Fagaraş (Romania) & Mt Negoiu & $45.61 \mathrm{~N} / 24.54 \mathrm{E}$ & 2050 & \\
\hline & M CAR 7 & S Carpathians, Bucegi (Romania) & Piatra Arsa & $45.43 \mathrm{~N} / 25.45 \mathrm{E}$ & 2050 & \\
\hline & M DYN 1 & $\begin{array}{l}\text { Dynaric Alps (Bosnia and } \\
\text { Herzegovina) }\end{array}$ & Belashnica Mt. & $43.75 \mathrm{~N} / 18.22 \mathrm{E}$ & 2100 & \\
\hline & M DYN 2 & Dynaric Alps (Montenegro) & Durmitor Mts. & $43.16 \mathrm{~N} / 19.09 \mathrm{E}$ & 2100 & \\
\hline & M GM 4 & Sudetes (Poland) & Giant Mts, Mały Staw & $50.75 \mathrm{~N} / 15.79 \mathrm{E}$ & 1150 & $\begin{array}{l}\text { Dzialuk et al. 2012; } \\
\text { Boratyńska et al., } 2014\end{array}$ \\
\hline & M GM 5 & Sudetes (Poland) & $\begin{array}{l}\text { Giant Mts, Czarny } \\
\text { Kocioł }\end{array}$ & $50.79 \mathrm{~N} / 15.59 \mathrm{E}$ & 1200 & $\begin{array}{l}\text { Dzialuk et al. 2012; } \\
\text { Boratyńska et al., } 2014\end{array}$ \\
\hline & M GM 6 & Sudetes (Poland) & Śnieżne Kotły & $50.78 \mathrm{~N} / 15.57 \mathrm{E}$ & 1250 & $\begin{array}{l}\text { Dzialuk et al. 2012; } \\
\text { Boratyńska et al., } 2014\end{array}$ \\
\hline & M LT & W Carpathians (Slovakia) & Lover Tatra, Lysa & $48.98 \mathrm{~N} / 19.59 \mathrm{E}$ & 1500 & \\
\hline & M RM 1 & Pirin (Bulgaria) & Vikhren, above Bansko & $41.77 \mathrm{~N} / 23.42 \mathrm{E}$ & 2000 & \\
\hline & M RM 2 & Rila (Bulgaria) & Ribni Ezera & $42.09 \mathrm{~N} / 23.44 \mathrm{E}$ & 1950 & \\
\hline & M RM 3 & Rila (Bulgaria) & Chemerna above & $42.07 \mathrm{~N} / 23.50 \mathrm{E}$ & & \\
\hline & & & Semkovo) & & 2000 & \\
\hline & M TM 1 & W Carpathians, Tatra (Poland) & Dolina Pięciu Stawów & $49.22 \mathrm{~N} / 20.05 \mathrm{E}$ & 1710 & $\begin{array}{l}\text { Dzialuk et al. 2012; } \\
\text { Boratyńska et al., } 2014\end{array}$ \\
\hline & M TM 2 & W Carpathians, Tatra (Poland) & Grześ - Wołowiec & $49.22 \mathrm{~N} / 19.76 \mathrm{E}$ & 1670 & $\begin{array}{l}\text { Dzialuk et al. 2012; } \\
\text { Boratyńska et al., } 2014\end{array}$ \\
\hline & M VIT & Vitosha (Bulgaria) & Aleko Mt & $42.57 \mathrm{~N} / 23.27 \mathrm{E}$ & 1500 & \\
\hline \multirow[t]{10}{*}{ uncinata } & U A & W Alps (Italy) & Claviere & $44.96 \mathrm{~N} / 6.79 \mathrm{E}$ & 1800 & Dzialuk et al. 2009 \\
\hline & $\mathrm{U}$ CEB & Cordillera Iberica (Spain) & Sierra Cebollera & $42.00 \mathrm{~N} / 2.64 \mathrm{~W}$ & 2050 & Dzialuk et al. 2009 \\
\hline & U GUD & Cordillera Iberica (Spain) & Sierra de Gúdar & $40.39 \mathrm{~N} / 0.61 \mathrm{~W}$ & 2000 & Dzialuk et al. 2009 \\
\hline & U MAS 1 & Massif Central (France) & $\begin{array}{l}\text { Col de la Croix de } \\
\text { Morand, }\end{array}$ & $45.60 \mathrm{~N} / 2.86 \mathrm{E}$ & 1350 & Dzialuk et al. 2009 \\
\hline & U MAS 2 & Massif Central (France) & Margaride Mts, Bouviers & $44.76 \mathrm{~N} / 3.53 \mathrm{E}$ & 1400 & Dzialuk et al. 2009 \\
\hline & U PYR 1 & W Pyrenees (Spain) & Belagua & $42.93 \mathrm{~N} / 0.67 \mathrm{~W}$ & 1700 & Dzialuk et al. 2009 \\
\hline & U PYR 2 & Central Pyrenees (Spain) & Benasque, Maladeta & $42.69 \mathrm{~N} / 0.66 \mathrm{E}$ & 2050 & Dzialuk et al. 2009 \\
\hline & U PYR 3 & Central Pyrenees (Andorra) & Vall de Ransol & $42.63 \mathrm{~N} / 1.60 \mathrm{E}$ & 2000 & Dzialuk et al. 2009 \\
\hline & UPYR 5 & E Pyrenees (Spain) & Vall de Núria & $42.38 \mathrm{~N} / 2.18 \mathrm{E}$ & 2150 & Dzialuk et al. 2009 \\
\hline & U PYR 7 & Central Pyrenees (Spain) & Port de la Bonaigua & $42.63 \mathrm{~N} / 1.02 \mathrm{E}$ & 2100 & Dzialuk et al. 2009 \\
\hline \multirow[t]{3}{*}{ uliginosa } & UL BAT & Sudetes (Poland) & $\begin{array}{l}\text { Stołowe Mts, Batorów } \\
\text { Moor }\end{array}$ & $50.46 \mathrm{~N} / 16.38 \mathrm{E}$ & \multicolumn{2}{|c|}{ 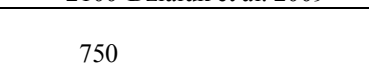 } \\
\hline & UL TOP & Sudetes (Poland) & $\begin{array}{l}\text { Bystrzyckie Mts, } \\
\text { Topieliska }\end{array}$ & $50.35 \mathrm{~N} / 16.41 \mathrm{E}$ & \multicolumn{2}{|l|}{800} \\
\hline & UL WEG & Silesian Lowland (Poland) & $\begin{array}{l}\text { Węgliniec Nature } \\
\text { Reserve }\end{array}$ & $51.29 \mathrm{~N} / 15.23 \mathrm{E}$ & 190 & \\
\hline
\end{tabular}


Table 2 Description of the loci studied

\begin{tabular}{|c|c|c|c|c|c|c|c|c|}
\hline \multirow{2}{*}{ Locus } & \multirow{2}{*}{ Dye $^{a}$} & \multirow{2}{*}{$\begin{array}{l}\text { Primer } \\
\text { conc. }(\mathrm{nM})\end{array}$} & \multirow{2}{*}{ Taxon $^{b}$} & \multirow{2}{*}{$\begin{array}{l}\text { Allele } \\
\text { number }\end{array}$} & \multicolumn{2}{|c|}{ Range } & \multicolumn{2}{|c|}{$\mathrm{Size}^{\mathrm{c}}$} \\
\hline & & & & & $\min$. & $\max$. & allele & freq. \\
\hline \multirow[t]{3}{*}{ РCP87314 } & FAM & 30 & mugo s.s. & 7 & 109 & 115 & 113 & 0.335 \\
\hline & & & uncinata & 5 & 109 & 113 & 112 & 0.393 \\
\hline & & & uliginosa & 6 & 109 & 114 & 111 & 0.264 \\
\hline \multirow[t]{3}{*}{ РCP41131 } & FAM & 200 & mugo s.s. & 7 & 138 & 144 & 142 & 0.557 \\
\hline & & & uncinata & 8 & 138 & 148 & 142 & 0.617 \\
\hline & & & uliginosa & 4 & 140 & 143 & 142 & 0.560 \\
\hline \multirow[t]{3}{*}{ Pt26081 } & VIC & 25 & mugo s.s. & 6 & 102 & 107 & 105 & 0.598 \\
\hline & & & uncinata & 4 & 103 & 106 & 106 & 0.387 \\
\hline & & & uliginosa & 4 & 103 & 106 & 105 & 0.440 \\
\hline \multirow[t]{3}{*}{ Pt15169 } & VIC & 60 & mugo s.s. & 7 & 119 & 125 & 122 & 0.599 \\
\hline & & & uncinata & 5 & 120 & 124 & 122 & 0.563 \\
\hline & & & uliginosa & 5 & 120 & 124 & 122 & 0.516 \\
\hline \multirow[t]{3}{*}{ Pt36480 } & VIC & 250 & mugo s.s. & 4 & 139 & 142 & 141 & 0.552 \\
\hline & & & uncinata & 3 & 140 & 142 & 141 & 0.940 \\
\hline & & & uliginosa & 6 & 140 & 148 & 141 & 0.538 \\
\hline \multirow[t]{3}{*}{ Pt45002 } & VIC & 60 & mugo s.s. & 11 & 159 & 169 & 164 & 0.517 \\
\hline & & & uncinata & 7 & 161 & 168 & 164 & 0.733 \\
\hline & & & uliginosa & 7 & 160 & 166 & 164 & 0.670 \\
\hline \multirow[t]{3}{*}{ PCP102652 } & NED & 40 & mugo s.s. & 6 & 108 & 115 & 112 & 0.986 \\
\hline & & & uncinata & 3 & 111 & 113 & 112 & 0.993 \\
\hline & & & uliginosa & 3 & 108 & 112 & 112 & 0.967 \\
\hline \multirow[t]{3}{*}{ Pt71936 } & NED & 75 & mugo s.s. & 12 & 138 & 151 & 148 & 0.347 \\
\hline & & & uncinata & 11 & 136 & 150 & 148 & 0.233 \\
\hline & & & uliginosa & 6 & 143 & 148 & 147 & 0.429 \\
\hline \multirow[t]{3}{*}{ PCP1289 } & PET & 25 & mugo s.s. & 6 & 101 & 106 & 102 & 0.679 \\
\hline & & & uncinata & 8 & 101 & 110 & 102 & 0.737 \\
\hline & & & uliginosa & 3 & 101 & 103 & 102 & 0.593 \\
\hline \multirow[t]{3}{*}{ Pt30204 } & PET & 100 & mugo s.s. & 9 & 138 & 147 & 143 & 0.480 \\
\hline & & & uncinata & 8 & 141 & 148 & 143 & 0.520 \\
\hline & & & uliginosa & 5 & 141 & 145 & 142 & 0.330 \\
\hline \multicolumn{9}{|c|}{${ }^{\mathrm{a}}$ forward primer } \\
\hline
\end{tabular}


Table 3 Haplotypic diversity and differentiation statistics estimated across populations of Pinus mugo s.l.

\begin{tabular}{|c|c|c|c|c|c|c|c|c|c|c|c|}
\hline Location & Population & $\mathrm{n}$ & $A_{h}$ & $\% \mathrm{PD}$ & $H_{r}$ & $P_{h}$ & $N_{e}$ & $H_{e}$ & $F_{S T}$ & $\# F_{S T}$ & $D_{s h}^{2}$ \\
\hline P. mugo s.s. & & 940 & 566 & 60.2 & 24.11 & & 267.92 & 0.997 & & & 8.43 \\
\hline \multirow[t]{11}{*}{ Alps } & M A 1 & 30 & 27 & 90.0 & 26.62 & 23 & 25.00 & 0.993 & 0.142 & 42 & 6.66 \\
\hline & M A 10 & 33 & 17 & 51.5 & 16.57 & 5 & 10.57 & 0.934 & 0.108 & 36 & 6.16 \\
\hline & M A 11 & 30 & 24 & 80.0 & 23.64 & 19 & 12.50 & 0.952 & 0.162 & 42 & 6.47 \\
\hline & M A 2 & 30 & 25 & 83.3 & 24.67 & 22 & 21.43 & 0.986 & 0.211 & 42 & 4.73 \\
\hline & M A 3 & 30 & 27 & 90.0 & 26.60 & 20 & 23.68 & 0.991 & 0.134 & 42 & 6.44 \\
\hline & M A 4 & 30 & 20 & 66.7 & 19.78 & 13 & 14.06 & 0.961 & 0.116 & 41 & 5.97 \\
\hline & M A 5 & 30 & 21 & 70.0 & 20.76 & 11 & 16.07 & 0.970 & 0.067 & 31 & 7.08 \\
\hline & M A 6 & 30 & 27 & 90.0 & 26.62 & 24 & 25.00 & 0.993 & 0.126 & 42 & 5.39 \\
\hline & M A 7 & 29 & 18 & 62.1 & 17.90 & 9 & 14.25 & 0.963 & 0.073 & 36 & 7.76 \\
\hline & M A 8 & 33 & 19 & 57.6 & 18.53 & 9 & 14.14 & 0.958 & 0.081 & 40 & 6.27 \\
\hline & M A 9 & 26 & 23 & 88.5 & 23.00 & 12 & 17.79 & 0.982 & 0.090 & 39 & 9.43 \\
\hline \multirow[t]{2}{*}{ Dynaric Alps } & M DYN 1 & 30 & 27 & 90.0 & 26.62 & 13 & 25.00 & 0.993 & 0.095 & 40 & 7.80 \\
\hline & M DYN 2 & 30 & 28 & 93.3 & 27.59 & 18 & 26.47 & 0.995 & 0.099 & 42 & 4.92 \\
\hline \multirow[t]{7}{*}{ E Carpathians } & M CAR 1 & 30 & 24 & 80.0 & 23.68 & 18 & 19.57 & 0.982 & 0.193 & 40 & 4.90 \\
\hline & M CAR 2 & 27 & 20 & 74.1 & 19.99 & 16 & 13.76 & 0.963 & 0.108 & 42 & 9.95 \\
\hline & M CAR 3 & 31 & 25 & 80.6 & 24.52 & 14 & 21.36 & 0.985 & 0.113 & 35 & 7.34 \\
\hline & M CAR 4 & 32 & 29 & 90.6 & 28.12 & 16 & 25.60 & 0.992 & 0.130 & 36 & 4.07 \\
\hline & M CAR 5 & 29 & 25 & 86.2 & 24.79 & 17 & 19.56 & 0.983 & 0.095 & 37 & 5.82 \\
\hline & M CAR 6 & 30 & 29 & 96.7 & 28.56 & 20 & 28.13 & 0.998 & 0.116 & 36 & 7.58 \\
\hline & M CAR 7 & 27 & 25 & 92.6 & 24.98 & 18 & 22.09 & 0.992 & 0.145 & 37 & 7.27 \\
\hline \multirow[t]{3}{*}{ W Carpathians } & M LT & 30 & 28 & 93.3 & 27.59 & 20 & 26.47 & 0.995 & 0.079 & 42 & 10.10 \\
\hline & M TM 1 & 33 & 26 & 78.8 & 25.10 & 8 & 20.55 & 0.981 & 0.085 & 40 & 6.60 \\
\hline & M TM 2 & 33 & 25 & 75.8 & 24.11 & 12 & 17.29 & 0.972 & 0.078 & 37 & 6.16 \\
\hline \multirow[t]{3}{*}{ Sudetes } & M GM 4 & 31 & 21 & 67.7 & 20.64 & 6 & 14.79 & 0.963 & 0.064 & 32 & 5.52 \\
\hline & M GM 5 & 33 & 20 & 60.6 & 19.44 & 5 & 13.79 & 0.956 & 0.078 & 36 & 8.35 \\
\hline & M GM 6 & 32 & 21 & 65.6 & 20.54 & 5 & 15.06 & 0.964 & 0.068 & 30 & 5.92 \\
\hline \multirow[t]{4}{*}{ Balkan Mts. } & M RM 1 & 30 & 28 & 93.3 & 27.59 & 17 & 26.47 & 0.995 & 0.085 & 39 & 8.08 \\
\hline & M RM 2 & 30 & 18 & 60.0 & 17.76 & 8 & 7.03 & 0.887 & 0.115 & 42 & 5.17 \\
\hline & M RM 3 & 30 & 26 & 86.7 & 25.65 & 18 & 23.68 & 0.991 & 0.091 & 33 & 9.16 \\
\hline & M VIT & 31 & 30 & 96.8 & 29.31 & 20 & 29.12 & 0.998 & 0.097 & 35 & 7.06 \\
\hline Apennines & M App & 30 & 21 & 70.0 & 20.75 & 16 & 15.52 & 0.968 & 0.161 & 42 & 4.42 \\
\hline P. uncinata & & 300 & 159 & 53.0 & 19.74 & & 57.92 & 0.986 & & & 8.24 \\
\hline Alps & U A & 30 & 20 & 66.7 & 19.76 & 8 & 12.50 & 0.952 & 0.108 & 34 & 4.65 \\
\hline \multirow[t]{2}{*}{ Cordillera Iber. } & U CEB & 30 & 25 & 83.3 & 24.65 & 24 & 20.46 & 0.984 & 0.150 & 42 & 12.67 \\
\hline & U GUD & 30 & 13 & 43.3 & 12.84 & 7 & 5.11 & 0.832 & 0.240 & 43 & 7.57 \\
\hline \multirow[t]{2}{*}{ Massiff Central } & U MAS 1 & 30 & 26 & 86.7 & 25.62 & 11 & 20.46 & 0.984 & 0.107 & 35 & 6.29 \\
\hline & U MAS 2 & 30 & 30 & 100.0 & 29.53 & 26 & 30.00 & 1.000 & 0.129 & 42 & 12.46 \\
\hline \multirow[t]{5}{*}{ Pyrenees } & U PYR 1 & 30 & 22 & 73.3 & 21.75 & 7 & 18.00 & 0.977 & 0.116 & 37 & 5.71 \\
\hline & U PYR 2 & 30 & 23 & 76.7 & 22.70 & 4 & 16.07 & 0.970 & 0.101 & 35 & 5.37 \\
\hline & U PYR 3 & 30 & 25 & 83.3 & 24.67 & 11 & 21.43 & 0.986 & 0.101 & 36 & 5.24 \\
\hline & U PYR 5 & 30 & 22 & 73.3 & 21.75 & 6 & 17.31 & 0.975 & 0.140 & 38 & 3.21 \\
\hline & U PYR 7 & 30 & 22 & 73.3 & 21.73 & 9 & 15.52 & 0.968 & 0.142 & 38 & 3.73 \\
\hline P. uliginosa & & 91 & 69 & 75.8 & 19.11 & & $\mathbf{5 0 . 8 0}$ & 0.991 & & & 10.29 \\
\hline \multirow{2}{*}{ Sudetes } & UL BAT & 30 & 17 & 56.7 & 16.84 & 6 & 10.98 & 0.940 & 0.108 & 41 & 5.79 \\
\hline & UL TOP & 30 & 23 & 76.7 & 22.73 & 18 & 19.57 & 0.982 & 0.108 & 42 & 11.03 \\
\hline Silesian Lowl. & UL WEG & 31 & 29 & 93.5 & 28.36 & 29 & 27.46 & 0.996 & 0.194 & 42 & 7.92 \\
\hline P. mugo s.l. & & 1331 & 757 & 56.9 & 24.28 & 14 & 19.11 & 0.997 & & & 8.98 \\
\hline$\chi^{2}$ & & & 0.49 & 0.55 & 0.53 & 2.75 & 0.42 & 0.38 & 4.24 & 2.57 & $\frac{0.50}{2.34}$ \\
\hline$\stackrel{\sim}{P}$ & & & 0.78 & 0.75 & 0.76 & 0.25 & 0.81 & 0.83 & 0.12 & 0.26 & 0.31 \\
\hline
\end{tabular}

$\mathrm{n}$ - a sample size; $A_{h}$ - observed number of haplotypes; PD - proportion distinguishable; $H_{r}$ - rarefaction standardized haplotype richness; $P_{h}$ - number of private haplotypes, $N_{e}$ - effective number of haplotypes; $H_{e}$ - unbiased haplotype diversity; $F_{S T}-$ mean pairwise $\mathrm{F}_{S T} ; \# F_{S T}-$ number of pairwise $F_{S T}$ with $\mathrm{P}<0.05 ; D_{s h}^{2}$ - within population genetic distance between haplotypes; $\chi^{2}$ and $P$ $-\mathrm{a}$ Kruskal-Wallis test for the difference in genetic diversity parameters between species. 
Table 4 Results of the analyses of molecular variance (AMOVA) assuming no population structuring, taxonomic and geographic grouping

\begin{tabular}{|c|c|c|c|c|c|}
\hline $\begin{array}{l}\text { Source of } \\
\text { variation }\end{array}$ & d.f. & $\begin{array}{c}\text { Sum of } \\
\text { squares }\end{array}$ & $\begin{array}{r}\text { Variance } \\
\text { components }\end{array}$ & $\begin{array}{l}\text { Percentage } \\
\text { of variation }\end{array}$ & $F$-statistics \\
\hline \multicolumn{6}{|c|}{ No population structuring } \\
\hline Among Pops & 43 & 545.509 & 0.3380 & 12.06 & \multirow{2}{*}{$F_{S T}=0.121^{*}$} \\
\hline Within Pops & 1287 & 3170.446 & 2.4634 & 87.94 & \\
\hline Among Pops & 43 & 3026.137 & 2.0634 & 20.59 & \multirow{2}{*}{$R_{S T}=0.206^{*}$} \\
\hline Within Pops & 1287 & 10244.478 & 7.9510 & 79.41 & \\
\hline \multicolumn{6}{|c|}{ Taxonomic grouping } \\
\hline Among Taxa & 2 & 108.215 & 0.1465 & 5.08 & $F_{C T}=0.051 *$ \\
\hline Among Pops & 41 & 437.294 & 0.2712 & 9.41 & $F_{S C}=0.099 *$ \\
\hline Within Pops & 1287 & 3170.446 & 2.4634 & 85.5 & $F_{S T}=0.144 *$ \\
\hline Among Taxa & 2 & 434.261 & 0.5190 & 5.04 & $R_{C T}=0.050 *$ \\
\hline Among Pops & 41 & 2591.875 & 1.8267 & 17.72 & $R_{S C}=0.187 *$ \\
\hline Within Pops & 1287 & 10244.478 & 7.9510 & 77.24 & $R_{S T}=0.228^{*}$ \\
\hline \multicolumn{6}{|c|}{ Geographic grouping } \\
\hline \multicolumn{6}{|l|}{ Among } \\
\hline Regions & 10 & 263.814 & 0.1575 & 5.58 & $F_{C T}=0.056^{*}$ \\
\hline Among Pops & 33 & 281.695 & 0.2009 & 7.12 & $F_{S C}=0.075^{*}$ \\
\hline Within Pops & 1287 & 3170.446 & 2.4634 & 87.30 & $F_{S T}=0.127^{*}$ \\
\hline \multicolumn{6}{|l|}{ Among } \\
\hline Regions & 10 & 1439.538 & 0.8458 & 8.35 & $R_{C T}=0.083^{*}$ \\
\hline Among Pops & 33 & 1586.599 & 1.3269 & 13.10 & $R_{S C}=0.143^{*}$ \\
\hline Within Pops & 1287 & 10244.478 & 7.9510 & 78.56 & $R_{S T}=0.214^{*}$ \\
\hline
\end{tabular}

* $P<0.001$ 
Table 5 Results of the analyses of molecular variance (AMOVA) among pairs of taxa.

\begin{tabular}{|c|c|c|c|c|c|}
\hline $\begin{array}{l}\text { Source of } \\
\text { variation }\end{array}$ & d.f. & $\begin{array}{l}\text { Sum of } \\
\text { squares }\end{array}$ & $\begin{array}{l}\text { Variance } \\
\text { components }\end{array}$ & $\begin{array}{l}\text { Percentage of } \\
\text { variation }\end{array}$ & $F$-statistics \\
\hline \multicolumn{6}{|c|}{ P. mugo s.s. vs $P$. uncinata } \\
\hline Among Taxa & 1 & 94.866 & 0.1862 & 6.42 & $F_{C T}=0.064^{* *}$ \\
\hline Among Pops & 39 & 398.444 & 0.2566 & 8.85 & $F_{S C}=0.095^{* *}$ \\
\hline Within Pops & 1199 & 2943.966 & 2.4554 & 84.72 & $F_{S T}=0.153^{* *}$ \\
\hline Among Taxa & 1 & 359.792 & 0.6534 & 6.32 & $R_{C T}=0.063^{* *}$ \\
\hline Among Pops & 39 & 2452.185 & 1.8188 & 17.59 & $R_{S C}=0.188^{* *}$ \\
\hline Within Pops & 1199 & 9432.454 & 7.8670 & 76.09 & $R_{S T}=0.239^{* *}$ \\
\hline \multicolumn{6}{|c|}{ P. mugo s.s. vs $P$. uliginosa } \\
\hline Among Taxa & 1 & 16.745 & 0.0326 & 1.14 & $F_{C T}=0.011^{\mathrm{ns}}$ \\
\hline Among Pops & 32 & 362.714 & 0.2902 & 10.15 & $F_{S C}=0.103^{* *}$ \\
\hline Within Pops & 997 & 2528.246 & 2.5359 & 88.71 & $F_{S T}=0.113^{* *}$ \\
\hline Among Taxa & 1 & 66.742 & 0.0579 & 0.62 & $R_{C T}=0.063^{\mathrm{ns}}$ \\
\hline Among Pops & 32 & 1826.742 & 1.6329 & 17.62 & $R_{S C}=0.177^{* *}$ \\
\hline Within Pops & 997 & 7554.744 & 7.5775 & 81.76 & $R_{S T}=0.182^{* *}$ \\
\hline \multicolumn{6}{|c|}{$P$. uncinata vs $P$. uliginosa } \\
\hline Among Taxa & 1 & 23.366 & 0.0931 & 3.50 & $F_{C T}=0.035^{*}$ \\
\hline Among Pops & 11 & 113.430 & 0.2670 & 10.03 & $F_{S C}=0.104^{* *}$ \\
\hline Within Pops & 378 & 868.680 & 2.2981 & 86.47 & $F_{S T}=0.135^{* *}$ \\
\hline Among Taxa & 1 & 161.250 & 0.5622 & 4.59 & $R_{C T}=0.046^{*}$ \\
\hline Among Pops & 11 & 904.824 & 2.4282 & 19.82 & $R_{S C}=0.208^{* *}$ \\
\hline Within Pops & 378 & 3501.757 & 9.2639 & 75.60 & $R_{S T}=0.244^{* *}$ \\
\hline
\end{tabular}

${ }^{*} P<0.05$

${ }^{\text {ns }}$ values not significantly different from zero $(P \geq 0.05)$ 
Table 6. Matrix of pairwise $F_{\mathrm{ST}}$ between taxa of P. mugo complex.

\begin{tabular}{lll}
\hline Taxon & P. mugo s.s. & P. uncinata \\
\hline P. uncinata & 0.699 & \\
P. uliginosa & 0.029 & 0.558 \\
\hline
\end{tabular}

10

11

12

13

14

15

16

17

18

19

20

21

22

23

24

25

26

27

28

29

30

31

32

33

34

35

36

37

38

39

40

41

42

43

44

45

46

47

48

49

50

51

52

53

54

55

56

57

58

59

60 
Table 7 Significance test for the presence of the phylogeographical structure in P. mugo complex performed using SPAGeDi 1.3

\begin{tabular}{rlll}
\hline \multicolumn{1}{l}{ Taxon } & $R_{S T}$ & $p R_{S T}$ & $P$ \\
\hline P. mugo s.s. & 0.178 & 0.090 & 0.0005 \\
Alps & 0.251 & 0.118 & 0.0020 \\
Sudetes & -0.002 & -0.004 & 0.7653 \\
SE Carpathians & 0.085 & 0.026 & 0.0003 \\
W Carpathians & 0.050 & 0.024 & 0.1597 \\
Balkan Mts. & 0.090 & 0.069 & 0.3966 \\
\hline P. uncinata & 0.214 & 0.089 & 0.0086 \\
\hline P. uliginosa & 0.178 & 0.132 & 0.2433 \\
\hline P. mugo complex & 0.206 & 0.126 & 0.0012 \\
\hline
\end{tabular}

